\title{
FEMINISMO NEGRO NO BRASIL E LUTA POR RECONHECIMENTO: UM DIÁLOGO COM A TEORIA DA JUSTIÇA DE NANCY FRASER
}

\author{
BLACK FEMINISM IN BRAZIL AND FIGHT FOR RECOGNITION: A DIALOGUE \\ WITH NANCY FRASER'S THEORY OF JUSTICE
}

\author{
EL FEMINISMO NEGRO EN BRASIL Y LA LUCHA POR EL RECONOCIMIENTO: \\ UN DIÁLOGO CON LA TEORÍA DE LA JUSTICIA DE NANCY FRASER
}

\author{
FERNANDA DA SILVA LIMA \\ https://orcid.org/0000-0001-7406-0020 / http://lattes.cnpq.br/9242692113745540 / felima.sc@gmail.com \\ Universidade do Extremo Sul Catarinense (UNESC) \\ Criciúma, SC, Brasil.
}

Angélica AZEREgo Garcia CaPoral https://orcid.org/0000-0001-5877-2343 / http://lattes.cnpq.br/9898847097592243 / angelag98@hotmail.com Universidade do Extremo Sul Catarinense (UNESC) Criciúma, SC, Brasil.

\begin{abstract}
RESUMO
Este artigo tem por objetivo analisar o processo de invisibilidade social sofrido pela mulher negra à luz da teoria crítica do reconhecimento de Nancy Fraser. 0 artigo apresenta a seguinte problemática: De que forma as políticas de redistribuição e de reconhecimento, propostas por Nancy Fraser contribuem para a luta do movimento feminista negro, no intuito de afirmar as mulheres negras como sujeito identitário e político, possibilitando a sua participação social paritária e, assim, promover um novo parâmetro normativo de justiça? A hipótese de trabalho está baseada na concepção de que, tanto o estudo das relações raciais no Brasil, como as teorias feministas tradicionais ignoram as demandas das mulheres negras. 0 estudo é desenvolvido em três partes: a) compreender a teoria das relações raciais no Brasil e o processo histórico da luta antirracista; b) entender a necessidade das mulheres negras em buscar um pensamento feminista negro; c) articular os estudos raciais e feministas com a teoria da justica de Nancy Fraser. 0 método é dedutivo, envolvendo pesquisa bibliográfica e procedimento monográfico.
\end{abstract}

Palavras-chave: Direitos Humanos; Feminismo negro; Reconhecimento; Relações Raciais; Teoria da Justiça.

\section{ABSTRACT}

This article aims to analyze the process of social invisibility suffered by black women in the light of Nancy Fraser recognition critical theory. The article presents the following problematic: How does the politics of redistribution and recognition proposed by Nancy Fraser contribute to the struggle of the black feminist movement, in order to affirm black women as an identity and political subject, enabling their equal social participation and thus promote a new normative parameter of justice? The hypothesis is based on the conception that both the study of racial relations in Brazil and traditional feminist theories ignore the demands of black women. The study is developed in three parts: a) understanding the theory of race relations in Brazil and the historical process of antiracist struggle; b) to uncover the invisibility of the black woman through the studies on black feminism; c) articulate racial and feminist studies with Nancy Fraser's theory of justice. The method is deductive, involving bibliographic research and monographic procedure.

Keywords: Human Rights; Black feminism; Recognition; Racial Relations; Justice Theory. 
FEMINISMO NEGRO NO BRASIL E LUTA POR RECONHECIMENTO: UM DIÁLOGO COM A TEORIA DA JUSTIÇA DE NANCY FRASER

FERNANDA DA SILVA LIMA ANGÉLICA AZEREGO GARCIA CAPORAL

\section{RESUMEN}

Este artículo pretende analizar el proceso de invisibilidad social que sufren las mujeres negras a la luz de la teoría crítica del reconocimiento de Nancy Fraser. El artículo presenta el siguiente problema: ¿Cómo contribuyen las políticas de redistribución y reconocimiento propuestas por Nancy Fraser a la lucha del movimiento feminista negro para afirmar a las mujeres negras como una identidad y un sujeto político, permitiendo su participación social igualitaria? ¿Y así promover un nuevo parámetro normativo de la justicia? La hipótesis de trabajo se basa en la concepción de que tanto el estudio de las relaciones raciales en Brasil como las teorías feministas tradicionales ignoran las demandas de las mujeres negras. El estudio se desarrolla en tres partes: a) comprender la teoría de las relaciones raciales en Brasil y el proceso histórico de lucha antirracista; b) comprender la necesidad de que las mujeres negras persigan el pensamiento feminista negro; c) articular los estudios raciales y feministas con la teoría de la justicia de Nancy Fraser. El método es deductivo, involucrando investigación bibliográfica y procedimiento monográfico.

Palabras clave: derechos humanos; Feminismo negro; Reconocimiento; Relaciones raciales; Teoría de la justicia.

\section{SUMÁRIO}

INTRODUÇAO; 1 RACISMO E ANTIRRACISMO NO BRASIL: CONSTRUINDO UMA RACIONALIDADE DE RESISTÊNCIA; 2 MULHERES NEGRAS E PENSAMENTO FEMINISTA NEGRO; 3 REDISTRIBUIÇÃO OU RECONHECIMENTO?; CONCLUSÃO; REFERÊNCIAS.

\section{INTRODUÇÃO}

Este texto tem um propósito insurgente. É o de conferir o espaço e o lugar da fala a partir dos estudos do feminismo negro. O termo carrega em si, ao menos, dois fatores de subordinação que subjugam as mulheres negras - o sexismo e o racismo. Logo, é a partir da emergência de constituir as mulheres negras como sujeito político, identitário e não subalterno que se propõe esta reflexão. Ser sujeito é falar por si próprio/a. O contrário disso é a objetificação, cujo processo de descrição tem sido feito por outros/as, a partir da visão do/a outro/a 1 .

Por muito tempo a história das mulheres negras, seja no Brasil, na América Latina ou em outras partes do mundo, foi contada de forma a objetificá-las. Da mesma forma, a teoria das relações raciais no Brasil só alcançou desdobramentos mais críticos, afrontando o mito da democracia racial, na segunda metade do século passado - embora ele ainda persista

\footnotetext{
10 outro nesse contexto é o colonizador, o homem branco europeu, que como grupo hegemônico cultural e economicamente, "apenas tolera o grupo culturalmente diferenciado, quando o faz, e desde que este grupo consuma o seu excedente e mantenha as suas práticas "estranhas" no âmbito privado de seus redutos concedidos (pelo primeiro grupo). Em troca, ou melhor, como manifestação maculada de respeito, o grupo hegemônico permite que se fale do grupo minoritário em alguns espaços, desde que essa "divulgação do outro" não represente nenhuma ameaça à hierarquia que permanece existindo". Cf: BARALDI, Camila Bibiana Freitas; PERUZZO, Pedro Pulzatto. DEMOCRACIA E DIREITOS HUMANOS: A PARTICIPAÇÃO SOCIAL DAS MINORIAS. Revista Eletrônica do Curso de Direito da UFSM, Santa Maria, RS, v. 10 , n. 1 , p. $347-370$, out. 2015 , p. 354)
} 
racionalmente forjado nos ideais meritocráticos que fundam o modelo econômico na sociedade capitalista, que "gera enormes desigualdades e opressão com uma ideologia político-jurídica que promete dignidade e equidade" de forma a criar a "falsa expectativa nos países em desenvolvimento de que também podem chegar ao padrão econômico ocidental". ${ }^{2}$

Esta análise também pressupõe enxergar o Brasil como o país periférico no sistema mundo, considerando seu espaço geopolítico, histórico e colonial. Uma abordagem crítica sobre direitos humanos da população negra, especificamente das mulheres negras, “[...] no sentido de assegurar o protagonismo dos grupos historicamente alijados dos processos de tomadas de decisão sobre assuntos públicos”3 ${ }^{3}$ requer, primeiramente, a descolonização do pensamento. Descolonizar o pensamento implica na interpretação do mundo sob a perspectiva do 'outro', da 'diferença' e da 'pluralidade', ou seja, "trata-se da busca do horizonte de um outro conhecimento, de uma outra forma de pensar [...].". ${ }^{4}$

Não se quer negar com este estudo a trajetória dos movimentos feministas tradicionais e dos estudos de gênero, responsáveis, em grande medida, pela conquista formal e material de direitos às mulheres, mas se enfatiza, que estes estudos, ao não incorporarem a questão da raça, tornam-se insuficientes para a constituição do sujeito mulher negra, simplesmente porque as mulheres negras possuíam e ainda possuem pautas de lutas diferentes. Da mesma forma, o estudo da trajetória histórica e social das relações raciais no País, também não oportunizou o protagonismo e a visibilidade das mulheres negras, resquício de uma sociedade estruturada em bases sexistas e patriarcais.

O objetivo deste artigo é analisar o processo de invisibilidade social sofrido pela mulher negra ao conciliar a necessidade de investimento em políticas de redistribuição e de reconhecimento à luz da teoria da justiça de Nancy Fraser. Infere-se que a invisibilidade da mulher negra decorre de múltiplas discriminações, que se entrecruzam, de forma interseccional, podendo ser elas discriminação de gênero, raça, classe social ou quaisquer outros fatores que contribuem para a produção de subordinação.

É urgente, para tanto, romper com o pensamento colonial que, tradicionalmente tem ignorado a discussão de raça e gênero, não permitindo a mulher negra se constituir enquanto

${ }^{2}$ MULLER, Crisna Maria; MOREIRA, Dirceia. A EFETIVAÇÃO DOS DIREITOS HUMANOS NA CONCEPÇÃO MULTICULTURAL: CONSTRUÇÃO DA CIDADANIA COSMOPOLITA. Revista Eletrônica do Curso de Direito da UFSM, Santa Maria, RS, v. 11, n. 1, p. 71-89, jun. 2016, p. 77.

3 BARALDI, Camila Bibiana Freitas; PERUZZO, Pedro Pulzatto. DEMOCRACIA E DIREITOS HUMANOS: A PARTICIPAÇÃO SOCIAL DAS MINORIAS. Revista Eletrônica do Curso de Direito da UFSM, Santa Maria, RS, v. 10, n. 1, p. 347-370, out. 2015, p. 350.

4 WOLKMER, Antônio Carlos. Para uma sociologia jurídica no Brasil: desde uma perspectiva crítica e descolonial. Revista Brasileira de Sociologia do Direito, v. 4, n. 3, set./dez. 2017, p. 19-20 
sujeito político não subalterno, acarretando na sua invisibilidade perante os movimentos sociais - negros e feministas. Justifica-se a escolha por Nancy Fraser e, assim, promover o diálogo com as feministas negras, porque a autora, além de “[...] discutir os aspectos filosóficos e sociológicos da teoria do reconhecimento, tem seu inegável interesse principal localizado na análise dos recentes movimentos sociais e das lutas políticas que os singularizam.". ${ }^{5}$ Ao mesmo tempo, como será demonstrado, Nancy Fraser, tem ungido um debate acadêmico propondo questões mais concretas e conferindo voz própria aos movimentos sociais, transformando suas pautas em luta política capaz de relacionar melhor a teoria com a prática. ${ }^{6}$

Para o desenvolvimento do trabalho, parte-se da seguinte problemática: De que forma as políticas de redistribuição e de reconhecimento, propostas por Nancy Fraser contribuem para a luta do movimento feminista negro, no intuito de afirmar as mulheres negras como sujeito identitário e político, possibilitando a sua participação social paritária e, assim, promover um novo parâmetro normativo de justiça?

A hipótese de trabalho está baseada na concepção de que, tanto o estudo das relações raciais no Brasil, como as teorias feministas tradicionais ignoram as demandas das mulheres negras, sendo urgente a construção do feminismo negro enquanto campo teórico sustentador de uma nova práxis intercultural.

O estudo é desenvolvido em três etapas. Na primeira busca-se compreender a teoria das relações raciais no Brasil e o processo histórico da luta antirracista. Estudar o processo de invisilibidade da mulher negra através dos estudos sobre o feminismo negro enquanto campo teórico. E por fim, verificar a possibilidade de articular os estudos raciais e feministas com a teoria da justiça proposta por Nancy Fraser.

Nesta pesquisa é utilizado o método dedutivo, envolvendo a técnica de pesquisa da documentação indireta, uma vez que o trabalho se baseia também em pesquisa bibliográfica e documental, e como método de procedimento, o monográfico.

\footnotetext{
${ }^{5}$ MATTOS, Patrícia de Castro. A sociologia política do reconhecimento: as contribuições de Charles Taylor, Axel Honneth e Nancy Fraser. São Paulo: Annablume, 2006, p. 16.

${ }^{6}$ MATTOS, Patrícia de Castro. A sociologia política do reconhecimento: as contribuições de Charles Taylor, Axel Honneth e Nancy Fraser. São Paulo: Annablume, 2006, p. 16.
} 


\section{RACISMO E ANTIRRACISMO NO BRASIL: CONSTRUINDO UMA RACIONALIDADE DE RESISTÊNCIA}

A luta pela igualdade racial na sociedade brasileira não é fenômeno recente, sendo anterior à própria abolição da escravatura, ocorrida legalmente em 13 de maio de 1888, e passando por várias fases, de avanços e retrocessos ao longo do século XX. De acordo com Fernandes $^{7}$ a abolição da escravatura não significou aos grupos raciais negros melhores condições de vida, ao contrário, os negros permaneceram à margem da sociedade, com baixos índices de participação econômica, social e cultural. Por isso Fernandes menciona a necessidade alcançar uma segunda abolição, e Davis ${ }^{8}$ afirma que é necessária uma abolição da própria democracia, capaz de assegurar a garantia de direitos humanos e fundamentais à população negra.

Assim, a aprovação da Lei de Abolição da Escravatura em 1888 e a Proclamação da República no ano seguinte não trouxeram mudanças significativas na vida dos grupos raciais negros, ao contrário, não houve uma mudança na racionalidade e na cultura social para o respeito à diversidade étnico-racial. No Brasil, por exemplo, o projeto de branqueamento foi implementado através do investimento em políticas imigratórias, antes mesmo do fim da escravidão.

De acordo com Rizzini ${ }^{9}$ os ideais positivistas e republicanos de 'ordem e progresso' impulsionaram a crescente industrialização, o crescimento e desenvolvimento dos centros urbanos de forma acentuada e desordenada, propiciada pela entrada maciça de imigrantes europeus. Viveu-se no País, pela primeira vez, uma condição em que a moradia tornou-se um problema nas suas principais capitais. Muitas pessoas habitavam conglomerados urbanos em periferias, e dentre estes grupos estavam os negros, deixados à margem da sociedade.

Além disso, a compreensão da dinâmica social, no que se refere às relações raciais no Brasil, tem como base fundadora o racismo científico importado da Europa ${ }^{10}$ a partir da segunda

\footnotetext{
${ }^{7}$ FERNANDES, Florestan. 0 negro no mundo dos brancos. Apresentação de Lilia Moritz Schwarcz. 2. ed. rev. São Paulo: Global, 2007, p. 171-172.

8 DAVIS, Angela. A democracia da abolição: para além do império das prisões e da tortura. Tradução Artur Neves Teixeira. Rio de Janeiro: DIFEL, 2009.

9 RIZZINI, Irma. Assistência à infância no Brasil: uma análise de sua construção. Rio de Janeiro: Ed. Universitária Santa Úrsula, 1993, p. 39.

10 Darwin (1981), ao publicar em 1859 “A origem das espécies”, foi responsável por uma verdadeira revolução no campo científico, principalmente porque derrubou a tese do criacionismo. Darwin baseava sua teoria em conceitos relacionados à "competição", "seleção do mais forte", "evolução" e "hereditariedade", os quais foram responsáveis pela disseminação da teoria evolucionista e aplicados aos
} 
FEMINISMO NEGRO NO BRASIL E LUTA POR RECONHECIMENTO: UM DIÁLOGO COM A TEORIA DA JUSTIÇA DE NANCY FRASER

FERNANDA DA SILVA LIMA ANGÉLICA AZEREGO GARCIA CAPORAL

metade do século XIX. O termo 'raça' começava a fazer parte do vocabulário corrente dos europeus e, mesmo tendo sido raramente definido com precisão pelos cientistas da época, serviu para diferenciar os grupos humanos. Concomitantemente a ideia da "raça" surgiu como um atributo de poder capaz de conferir o status de superioridade e de inferioridade entre os seres humanos, acarretando, portanto no seu processo de hierarquização ${ }^{11}$.

Importante compreender que as possíveis diferenças atribuíveis aos seres humanos e que acarretariam na hierarquização entre os indivíduos, não estava tão somente relacionada às suas características fisionômicas, mas sim aos elementos culturais ${ }^{12}$ constitutivos de sua identidade, tais como língua, religião, costumes, danças, músicas, entre outros.

Não foram apenas as teses do evolucionismo responsáveis pela produção do racismo científico, outras surgiram no mesmo período histórico e foram tão perversas quanto às anteriores, como a tese da Eugenia atribuída a Francis Galton, que previa a possibilidade de melhoramento da raça humana baseado nos efeitos da hereditariedade e na proibição de misturas entre raças (ideia de raça pura e de negação da mestiçagem). ${ }^{13}$ A central preocupação dos adeptos da teoria eugenista era a de sempre buscar o melhoramento ou o aprimoramento da raça humana, por isso condenavam a mestiçagem, pois a mestiçagem representaria a degeneração ou a decadência do gênero humano.

mais variados ramos da ciência, como Psicologia, Linguística, Sociologia Evolutiva, História Determinista e Antropologia.

11 "Considerando as diversas diferenças entre os seres humanos que habitavam as diversas regiões do planeta, possuindo as mais diversas cores - brancos, pretos, pardos, amarelos -, possuindo as mais diversas culturas, foi necessário, do ponto de vista do colonizador e do opressor, explicar em termos científicos que os seres humanos não eram todos iguais, e que as suas diferenças possibilitavam a criação de uma hierarquia, uma hierarquia entre as raças." Cf: LIMA, Fernanda da Silva. Os direitos humanos e fundamentais de crianças e adolescentes negros à luz da proteção integral: limites e perspectivas das políticas públicas de igualdade racial no Brasil. Tese. 337fl (Programa de Pós-Graduação em Direito) pela Universidade Federal de Santa Catarina, Florianópolis, 2015, p. 112.

12 François Laplatine, pertencente à escola da Antropologia Clássica, afirma que a figura do 'selvagem' sempre esteve associada ao homem mal, enquanto que do 'civilizado' correspondia ao homem branco, visto como o homem bom. Conforme destaca o autor, ao referir-se ao continente africano, os negros seriam incapazes

de alcançar qualquer estágio de civilização, permanecendo para sempre em posição hierárquica inferior àqueles que ele considerava civilizado, conforme trecho destacado de sua obra: Tudo na África, é nitidamente visto sob o signo da falta absoluta: os "negros" não respeitam nada, nem mesmo eles próprios, já que comem carne humana e fazem comércio de "carne" de seus próximos. Vivendo em uma ferocidade bestial inconsciente de si mesma, em uma selvageria em estado bruto, eles não têm moral, nem instituições sociais, religião ou Estado. Petrificados em uma desordem inexorável, nada, nem mesmo as forças da colonização, poderá nunca preencher o fosso que os separa da História universal da humanidade. Cf: LAPLATINE, François. Aprender Antropologia. Tradução Marie-Agnès Chauvel. São Paulo: Brasiliense, 1988, p. 45).

${ }^{13}$ SCHWARCZ, Lilia Moritz. 0 espetáculo das raças: cientistas, instituições e questão racial no Brasil 1870-1930. São Paulo: Companhia das Letras, 1993, p. 60. 
FEMINISMO NEGRO NO BRASIL E LUTA POR RECONHECIMENTO: UM DIÁLOGO COM A TEORIA DA JUSTIÇA DE NANCY FRASER

FERNANDA DA SILVA LIMA ANGÉLICA AZEREGO GARCIA CAPORAL

O percurso histórico das relações raciais no País demonstra que com o passar dos anos, já nas primeiras décadas do século XX, as teorias raciais deterministas vão perdendo força diante do fenômeno crescente da miscigenação da população. Nesse sentido, até mesmo a política imigracionista implementada com a finalidade de pôr em prática o projeto de branqueamento tornou-se incipiente, oportunizando a construção do que se pode chamar de 'elogio à mestiçagem, ${ }^{14}$ absorvida pelo discurso do branqueamento.

A tese da mestiçagem se desenvolve no Brasil na década de 1930, tendo como maior fomentador desta ideia Gilberto Freyre, cujas obras percorreram o mundo, com destaque a obra “Casagrande \& Senzala”. Freyre e seus seguidores ideológicos constaram que como o fenômeno da mestiçagem era predominante na sociedade brasileira, logo as teorias raciais não serviam mais. Era necessário repensar as relações raciais na sociedade brasileira abarcando a mestiçagem como fenômeno predominante e formador da identidade dos brasileiros.

Freyre ${ }^{15}$ destacou as características da sociedade patriarcal e relacionou a mestiçagem racial à ideia de convivência harmoniosa entre as diferentes raças que compõem a sociedade brasileira. Para Freyre a identidade nacional era formada por três raças principais: do negro, do índio e do europeu, fazendo um forte apelo para aceitação da mestiçagem no país. ${ }^{16}$

Ainda que o racismo biológico tenha perdido força e tenha, até mesmo, sido refutado, o racismo e a discriminação racial não cessaram em relação à população negra. Munanga esclarece que:

[...] o racismo passa, no decorrer dos anos, por uma complexidade de mutações em suas figuras sociais, culturais e discursivas. Em sua evolução, a ciência biológica demonstrou, já na segunda metade do século XX, que a raça não existe e, consequentemente, que são absurdas as crenças baseadas na superioridade e inferioridade raciais dos grupos humanos.

Porém, as crenças racistas não recuam, apesar de as pessoas terem mais acesso à ciência através da educação, o que mostra que a racionalidade em si não é suficiente para que todas as pessoas possam abrir mão de suas crenças racistas.

\footnotetext{
14 Alguns cientistas da época acreditavam que a mestiçagem brasileira se resolveria com o tempo, pois, uma vez considerado o branco como elemento superior, qualquer cruzamento de outra raça, por exemplo, o "negro" com o "branco", formaria um mestiço mais embranquecido. A mestiçagem foi absorvida pelo discurso do embranquecimento, baseada no entendimento de que, com a mistura destas raças, possivelmente a 'branca' prevaleceria, dando origem em poucos anos a uma nova composição racial da população brasileira (mais embranquecida). Este fenômeno foi assistido já nos anos 1960, com a popularização do termo 'moreno'. Cf: GUIMARÃES, Antônio Sérgio Alfredo. Preconceito Racial: modos, temas e tempos. São Paulo: Cortez, 2008. 2008, p. 32.

15 FREYRE, Gilberto. Casa-grande \& senzala. 40. ed. Rio de Janeiro: Record, 2000.

16 SCHWARCZ, Lilia Moritz. O espetáculo das raças: cientistas, instituições e questão racial no Brasil 1870-1930. São Paulo: Companhia das Letras, 1993, 111-113.
} 
FEMINISMO NEGRO NO BRASIL E LUTA POR RECONHECIMENTO: UM DIÁLOGO COM A TEORIA DA JUSTIÇA DE NANCY FRASER

FERNANDA DA SILVA LIMA ANGÉLICA AZEREGO GARCIA CAPORAL

Em outros termos, os racistas são movidos por outra racionalidade, que não é necessariamente científica. ${ }^{17}$

Logo, como afirmou Munanga, ao mesmo tempo em que a sociedade brasileira guia-se por outra forma de racionalidade racista, ela passa também a ignorar que o racismo existe. É o preconceito a ter preconceito ${ }^{18}$ ou o ainda, o racismo à brasileira, como bem demonstrou Gonzáles de forma irônica ${ }^{19}$ e com abordagem psicanalítica em seu texto "Racismo e Sexismo na cultura brasileira" publicado em 1984, conforme trecho que segue:

Racismo? No Brasil? Quem foi que disse? Isso é coisa de americano. Aqui não tem diferença porque todo mundo é brasileiro acima de tudo, graças a Deus. Preto aqui é bem tratado, tem o mesmo direito que a gente tem. Tanto é que, quando se esforça, ele sobe na vida como qualquer um. Conheço um que é médico: educadíssimo, culto, elegante e com umas feições tão finas...Nem parece preto. ${ }^{20}$

O pequeno trecho acima pode ilustrar muito bem os subterfúgios criados para, não só negar que o racismo persiste até os dias atuais, como para ignorar que ele é o principal elemento fundante da negação das diferenças, sob um suposto ideal de igualdade entre a população ou de harmonia entre as raças, algo que se sabe, nunca existiu. A perversidade da negação do racismo foi instituída na 'tese da democracia racial', tese esta negadora de qualquer desigualdade baseada na raça.

Por isso, em razão da tese da democracia racial e da superação dos estudos raciais estruturados em base econômica e classe social, foi primordial, tanto aos movimentos sociais negros, como à academia remodelar ou reconceituar o termo "raça". Raça atualmente é usado no âmbito da luta e da resistência do povo negro - e outros grupos também oprimidos em relação a sua cultura e identidade. É um termo político empregado apenas no mundo social e que se

17 MUNANGA, Kabengele. As ambigüidades do racismo à brasileira. In: KON, Noemi Moritz; ABUD, Cristiane Curi; SILVA, Maria Lúcia da. (orgs.) $O$ racismo e o negro no Brasil: questões para a psicanálise. São Paulo: Perspectiva, 2017, p. 33.

18 FERNANDES, Florestan. 0 negro no mundo dos brancos. Apresentação de Lilia Moritz Schwarcz. 2. ed. rev. São Paulo: Global, 2007.

19 "A primeira coisa que a gente percebe, nesse papo de racismo é que todo mundo acha que é natural. Que negro tem mais é que viver na miséria. Por quê? Ora, porque ele tem umas qualidades que não estão com nada: irresponsabilidade, incapacidade intelectual, criancice, etc. e tal. Daí, é natural que seja perseguido pela polícia, pois não gosta de trabalho sabe? Se não trabalha, é malandro e se é malandro é ladrão. Logo, tem que ser preso, naturalmente. Menor negro só pode ser pivete ou trombadinha, pois filho de peixe, peixinho é. Mulher negra, naturalmente, é cozinheira, faxineira, servente, trocadora de ônibus ou prostituta. Basta a gente ler jornal, ouvir rádio e ver televisão. Eles não querem nada. Portanto têm mais é que ser favelados. Cf: GONZÁLES, Lélia. Racismo e sexismo na cultura brasileira. Revista Ciências Sociais Hoje, Anpocs, n. 2, Rio de Janeiro, 1984, p. 225-226.

20 GONZÁLES, Lélia. Racismo e sexismo na cultura brasileira. Revista Ciências Sociais Hoje, Anpocs, n. 2, Rio de Janeiro, 1984, p. 226. 
preocupa em demonstrar que há diferenças entre os seres humanos, mas que estas diferenças não podem mais servir como instrumento de atribuição de status superioridade/inferioridade ou qualquer processo de subordinação de indivíduos ou grupos, uns contra os outros.

Para Hall ${ }^{21}$ "raça é uma categoria não científica, mas sim uma construção política e social. É uma categoria discursiva que em torno do qual se organiza um sistema de poder [...]", que gera exploração e exclusão. Acrescenta-se ainda, que raça também passa a ser categoria cultural para expressar as diferentes identidades que compõem os sujeitos e grupos que vivem em sociedade, que em razão de sua identidade ou de sua cultura também podem sofrer processos de exclusão - não necessariamente socioeconômica ${ }^{22}$ ou processos de injustiças ${ }^{23}$.

Logo, atualmente, negar a existência de raças é negar a existência do preconceito racial, do racismo e da discriminação racial. Todas estas teorias raciais, embora utilizadas em diferentes momentos históricos, fazem-se presentes até hoje na sociedade brasileira. 0 mito da democracia racial e de que somos uma sociedade mestiça, dificultam as discussões raciais no país. Isso porque, torna-se difícil se identificar ou ser identificado como negro. 0 mito torna invisível, mascara, "[...] encobre os conflitos raciais possibilitando a todos se reconhecerem como brasileiros e afastando das comunidades subalternas a tomada de consciência de suas características que teriam contribuído para a construção e expressão de uma identidade própria"24.

As teorias raciais são resquícios da cultura colonialista eurocêntrica, utilizadas até os dias atuais para distorcer a realidade em favor da elite branca com intuito de dominação econômica, política e social. Servem para desviar o foco das situações cotidianas de humilhação e racismo que assolam a população negra e parda e das desigualdades por elas vividas na saúde, educação, mercado de trabalho, acesso às terras, na medida em que promovem o mito da

21 HALL, Stuart. Da Diáspora: Identidades e mediações culturais. Tradução de Adelaine la Guardia Resende et al. Belo Horizonte: UFMG Editora, 2003, p. 69.

22 SANTOS, Boaventura de Sousa. Introdução para ampliar o cânone do reconhecimento, da diferença e da igualdade. In:__ (Org.). Reconhecer para libertar: os caminhos do cosmopolitismo multicultural. Rio de Janeiro: Civilização Brasileira, 2003a.

23 FRASER, Nancy. Redistribuição, Reconhecimento e Participação: Por uma Concepção Integrada da Justiça. In: SARMENTO, Daniel; IKAWA, Daniela; PIOVESAN, Flávia (Coords.). Igualdade, Diferença e Direitos Humanos. Rio de Janeiro: Lumen Juris, 2008.

${ }_{24}$ MUNANGA, Kabengele. As ambigüidades do racismo à brasileira. In: KON, Noemi Moritz; ABUD, Cristiane Curi; SILVA, Maria Lúcia da. (orgs.) $O$ racismo e o negro no Brasil: questões para a psicanálise. São Paulo: Perspectiva, 2017, p. 80. 
democracia racial, desagregando a formação de grupos e movimentos sociais de luta pelo reconhecimento das diferenças e pela igualdade de direitos ${ }^{25}$.

\section{MULHERES NEGRAS E PENSAMENTO FEMINISTA NEGRO}

Contar a trajetória de luta das mulheres negras não é tarefa fácil. Por muito tempo elas passaram invisíveis tanto aos movimentos sociais negros - que privilegiaram os homens negros no debate político -, como aos movimentos feministas mais tradicionais e até mesmo críticos que centravam sua atenção exclusiva na luta de mulheres brancas burguesas num primeiro momento, e posteriormente para incluir a classe como fator de subordinação, ignorando as demandas por raça. O fato é que as mulheres negras, mesmo presentes em ambos os movimentos, não possuíam força política capaz de serem ouvidas ou levadas a sério. A construção de um pensamento feminista negro ou do feminismo negro tem, portanto, origem na luta das mulheres negras por representatividade e por serem reconhecidas como sujeito político ${ }^{26}$.

No entanto, o que estes movimentos têm em comum para superar é justamente o caráter violento do racismo e do sexismo no capitalismo global ${ }^{27}$, alimentados pelas várias

${ }^{25}$ A permanência das concepções preconceituosas e discriminatórias em relação às minorias impede o enraizamento de práticas democráticas participativas, que visam à criação e ao reconhecimento de direitos ao sujeitos subalternizados, pois afetam e tornam impermeável a própria estrutura social. Sem a experiência da alteridade, que nos permite compreender as nossas diferenças a partir das diferenças dos outros, os instrumentos e foros de participação social podem acabar figurando como meras reproduções de uma lógica excludente já presente na estrutura social brasileira. Cf: BARALDI, Camila Bibiana Freitas; PERUZZO, Pedro Pulzatto. DEMOCRACIA E DIREITOS HUMANOS: A PARTICIPACÃO SOCIAL DAS MINORIAS. Revista Eletrônica do Curso de Direito da UFSM, Santa Maria, RS, v. 10, n. 1, p. 347-370, out. 2015. p. 360).

${ }^{26}$ A representatividade e o reconhecimento decorrem do exercício dos direitos políticos e de cidadania plena que pressupõe o rompimento com a visão objetificada atribuída as mulheres negras para se tornarem sujeitos e atrizes sociais e ainda um reconhecimento por parte do Estado-nação destes sujeitos marginalizados, pois como explicam Muller e Moreira: "o sujeito moderno só alcança sua humanidade quando adquire direitos políticos de cidadania e isso ocorre na medida em que pertenceria a um Estadonação". Desta forma, haveria uma exclusão, que não se limitaria às pessoas que são ou estão fora do território nacional, como o refugiado, mas afetaria também àqueles indivíduos que não são reconhecidos pelos seus próprios Estados". Cf: MULLER, Crisna Maria; MOREIRA, Dirceia. A EFETIVAÇ̃̃O DOS DIREITOS HUMANOS NA CONCEPÇÃO MULTICULTURAL: CONSTRUÇÃO DA CIDADANIA COSMOPOLITA. Revista Eletrônica do Curso de Direito da UFSM, Santa Maria, RS, v. 11, n. 1, p. 71-89, jun. 2016, p.77). Daí a necessidade das lutas dos movimentos das mulheres negras de maneira a garantir que a construção de um novo conceito de cidadania realizada "dentro de uma visão intercultural, onde se busca dar respostas para as necessidades específicas de grupos minoritários, [...] levando-se em consideração as diferenças existentes, uma vez que os direitos de cidadania originalmente foram definidos por e para os homens brancos" Id., p.83.

27 O fenômeno da globalização pode ser explicado por sua capacidade de transformação dos processos sócio-econômicos, que promove simultâneamente um amplo repertório de mudanças complexas que atinge diferentes áreas da vida social, da política à cultura, das relações humanas para a lei. Trata-se de um 
FEMINISMO NEGRO NO BRASIL E LUTA POR RECONHECIMENTO: UM DIÁLOGO COM A TEORIA DA JUSTIÇA DE NANCY FRASER

formas de discriminação e pela colonialidade do poder, do ser e do saber. ${ }^{28}$ Buscam 0 reconhecimento dos espaços de hegemonia, hierarquia e privilégio econômico, político e social, cultural e intelectual, dentre outros campos do poder, do ser e do saber dos quais reproduzem histórica e cotidianamente a voz e o pensamento branco, masculino e eurocêntrico. Demarcam a necessidade de visibilizar, enfrentar e transformar as estruturas e instituições que de maneira diferenciadora posicionam grupos, práticas e pensamentos dentro de uma ordem e lógica que, ao mesmo tempo, e ainda, é racial, moderno-ocidental e colonial, da qual todos consciente ou inconscientemente fomos e somos participantes, já que somos frutos da colonialidade ${ }^{29}$.

processo multifacetado e muitas vezes contraditório de fatores econômicos, políticos e sociais. Em termos econômicos o capitalismo global trouxe consigo um policentrismo decisivo que se materializa no surgimento de novos atores, como organizações não-governamentais, corporações transnacionais e os novos movimentos sociais, e tendeu a enfraquecer,fragmentar e até reestruturar o Estado. Cf: JULIOSCAMPUZANO, Alfonso de. CRISIS REGULATORIA, PLURALISMO JURÍDICO Y NUEVOS PARADIGMAS DEL DERECHO. Revista Eletrônica do Curso de Direito da UFSM, Santa Maria, RS, v. 11, n. 3, p. 1140-1160, dez. 2016, p. 1141). A globalização levou a um processo de descentralização e multiplicação das esferas legais de produção, tal fato demonstra a importância participação dos movimentos sociais em especial o das mulheres negras para criação e reconhecimento de direitos. (id., 1145)

${ }^{28}$ A construção teórica a respeito da colonialidade do saber, poder e do ser têm sido problematizada desde os anos 1990 pelo grupo de pesquisa Modernidade/Colonialidade que se constitui com uma perspectiva de apontar um projeto epistemológico novo, alternativo à modernidade eurocêntrica. Os pesquisadores principais do grupo são: o argentino Enrique Dussel, o peruano Aníbal Quijano, o argentinonorte-americanos Walter Mignolo, os porto-riquenhos Ramón Grosfogel e Nelson Maldonado-Torres, a norte-americana radicada no Equador Catherine Walsh, o colombiano Arturo Escobar e o norte americano Immanuel Walletrstein. Cf: OLIVEIRA, Luiz Fernandes de. Educação e militância decolonial. Rio de Janeiro: Editora Selo Novo, 2018, p. 44. 0 grupo também se propõe a discutir a colonialidade do poder, do saber e do ser como conceito analítico que "[...] ajudam a diferenciar modernidade de outros projetos civilizatórios e a explicar os caminhos pelos quais a colonialidade organiza múltiplas camadas de desumanização dentro da modernidade/colonialidade." Cf: MALDONADO-TORRES, Nelson. Analítica da colonialidade e da decolonialidade: algumas dimensões básicas. In: BERNADINO-COSTA, Joaze; MALDONADO-TORRES, Nelson; GROSFOGEL, Ramón (orgs.) Decolonialidade e pensamento afrodiaspórico. Belo Horizonte: Autêntica Editora, 2018, p. 42.

${ }^{29}$ Para que não se confunda os termos, Maldonado-Torres faz a distinção entre os termos colonialismo e colonialidade. De acordo com ele "Colonialismo denota uma relação política e econômica na qual a soberania de um povo reside no poder de outro povo ou nação e que constitui tal nação num império. Diferente desta idéia, a colonialidade se refere a um padrão de poder que emergiu como resultado do colonialismo moderno, porém ao invés de estar limitado a uma relação forma de poder entre os povos ou nações, refere-se à forma como o trabalho, o conhecimento, a autoridade e as relações intersubjetivas se articulam entre si através do mercado capitalista mundial e da idéia de raça. Assim, ainda que o colonialismo tenha precedido a colonialidade, esta sobrevive após o fim do colonialismo. A colonialidade se mantém viva nos manuais de aprendizagem, nos critérios para os trabalhos acadêmicos, na cultura, no senso comum, na autoimagem dos povos, nas aspirações dos sujeitos e em tantos outros aspectos da nossa experiência moderna. Enfim, respiramos a colonialidade na modernidade cotidianamente." Cf: MALDONADO-TORRES, Nelson. Sobre la colinialidade del ser: contribuciones AL desarrollo de un concepto. In: CASTRO-GOMEZ, Santiago; GROSFOGUEL, Ramón. (Orgs.) El giro decolonial: reflexiones para una diversidad espistémica más Allá del capitalismo global. Bogotá: Universidad Javeriana-Instituto Pensar/Universidad Central-IESCO/Siglo del Hombre Editores, 2007, p. 131. 
Alcançar uma nova configuração a fim de vencer a invisibilidade dos sujeitos subalternizados perpassa por pensamentos e práticas voltadas a outras formas de poder, de ser e de saber:

[...] implica em um trabalho de orientação de-colonial, dirigido a romper as correntes que ainda estão nas mentes [...] Um trabalho que procura desafiar e derrubar as estruturas sociais, políticas e epistêmicas da colonialidade estruturas até agora permanentes - que mantêm padrões de poder enraizados na racialização, no conhecimento eurocêntrico e na inferiorização de alguns seres como menos humanos. É a isso que me refiro quando falo da de-colonialidade. ${ }^{30}$

Conquanto, a importância dos movimentos sociais enquanto sujeitos coletivos não diz respeito apenas as suas lutas pela desconstrução da racionalidade eurocêntrica do poder, do ser e do saber, mas também a reconstrução de uma nova coletividade onde se elaboram identidades e se organizam práticas por meio das quais se defendem interesses, expressam-se vontades e constroem-se identidades, marcados por interações, processos de reconhecimento recíprocos, com composição mutável e intercambiável. ${ }^{31}$

A começar pelos movimentos negros, o que os distingue dos demais movimentos sociais por ser fruto de uma "negatividade histórica", conforme elucidam Barbosa e Santos:

O Movimento Negro se radica na tradição comum, ele busca da tradição os elementos que permitam perceber a si próprio. Simultaneamente, ele é a afirmação de uma negatividade histórica, de um papel desempenhado na história. Ele é a busca de outro si mesmo, para além da alteridade desse outro presente, que não é de si. ${ }^{32}$

Os movimentos negros, na construção dos seus saberes, denunciam que a escravidão, as teorias raciais, a colonização dos países africanos, os sofrimentos e a opressão trazidos por esses processos foram alternativas que poderiam ter sido evitadas no passado. ${ }^{33}$

Enquanto movimento social pode ser compreendido como um novo sujeito coletivo e político que juntamente com outros movimentos sociais, emergiu de forma mais orgânica na década de 1970 no cenário brasileiro, embora estivesse presente por meio de lutas desde o Brasil

\footnotetext{
${ }^{30}$ WALSH, Catherine. Interculturalidade crítica e pedagogia decolonial: in-surgir, re-existir e re-viver. In. CANDAU, Vera Maria (Org.). Educação intercultural na América Latina: entre concepções, tensões e propostas. Rio de Janeiro: 7 Letras, 2009, p. 24.

31 GOMES, Nilma Lino. O Movimento Negro Educador: saberes construídos nas lutas por emancipação. Rio de Janeiro: Vozes, 2017, p. 47.

32 BARBOSA, W.N. \& SANTOS, J.R. Atrás do muro da noite: dinâmicas das culturas afro-brasileiras.

Brasília: Minc/Fundação Cultural Palmares, 1994, p. 46.

${ }_{33}$ GOMES, Nilma Lino. O Movimento Negro Educador: saberes construídos nas lutas por emancipação. Rio de Janeiro: Vozes, 2017, p. 49.
} 
FEMINISMO NEGRO NO BRASIL E LUTA POR RECONHECIMENTO: UM DIÁLOGO COM A TEORIA DA JUSTIÇA DE NANCY FRASER

FERNANDA DA SILVA LIMA ANGÉLICA AZEREGO GARCIA CAPORAL

colônia $^{34}$, só foi consolidar-se no final da década de 70 com a abertura democrática que culminou no surgimento do Movimento Negro Unificado (MNU) em 1978. Este movimento visava o combate ao racismo, à discriminação racial e ao preconceito de cor.

Nesse sentido, o Movimento Negro Unificado caracterizou-se pela luta contra a opressão e emancipação dos negros no Brasil, buscou desconstruir o discurso do mito da democracia racial propondo uma rediscussão da identidade nacional. A democracia racial foi uma estratégia identitária induzida politicamente na era Vargas, década de 30, que visava à construção de uma homogeneidade nacional, sem conflitos, nem mesmo de classes, acentuando a ideia de povo unificado. ${ }^{35}$

Por meio dessa ardilosa construção do mito da democracia racial, o Brasil produziu historicamente, um tipo de "racismo insidioso, ambíguo, que se afirmava via sua própria negação e que está cristalizado na estrutura da nossa sociedade, tendo como sua principal característica a invisibilidade". O mito como narrativa transfigurada em discurso democrático destaca a igualdade de raças, entretanto uma falsa igualdade, que se baseia no "apagamento e na homogeneização das diferenças". ${ }^{36}$

$\mathrm{Na}$ mesma linha, a primeira onda do feminismo se manifestou mais publicamente no Brasil com a luta pelo direito ao voto, as sufragetes foram lideradas por Bertha Lutz, em 1910, uma das fundadoras da Federação Brasileira pelo Progresso Feminino. Sendo que o direito ao voto foi conquistado pelas mulheres somente em 1932, quando foi promulgado o Novo Código Eleitoral brasileiro.

Vale ainda destacar o movimento das operárias de ideologia anarquista da União das Costureiras, Chapeleiras e Classes Anexas, que em manifesto no ano de 1917 proclamavam: "Se

\footnotetext{
${ }^{34}$ Foram três as principais forças coletivas ou movimentos sociais que tiveram expressão em praticamente todo o território nacional no combate antirracista ao longo do século XX; são eles: a Frente Negra Brasileira (1930), o Teatro Experimental do Negro (1940) e o Movimento Negro Unificado (1978). Os três movimentos foram criados em contextos históricos diferenciados, e não coexistiram necessariamente, a pauta comum dos três está atrelada à busca por melhores condições de vida dos grupos raciais negros, que enquanto luta coletiva denunciavam o contexto de marginalização e exclusão pelo qual viviam os negros no Brasil. A Frente Negra Brasileira tinha como principal preocupação a alfabetização dos negros para possibilitar sua participação no processo político. O Teatro Experimental do Negro, voltava-se principalmente para as questões culturais, também preocupava-se em restaurar a autoimagem e a autoestima dos negros brasileiros. Cf: LIMA, Fernanda da Silva. Os direitos humanos e fundamentais de crianças e adolescentes negros à luz da proteção integral: limites e perspectivas das políticas públicas de igualdade racial no Brasil. Tese. 337fl (Programa de Pós-Graduação em Direito) pela Universidade Federal de Santa Catarina, Florianópolis, 2015.

35 SILVA, Marcelo L. da. A história no discurso do Movimento Negro Unificado: os usos políticos da história como estratégia de combate ao racismo. Campinas, SP, 2007. Dissertação. (Programa de pósgraduação em História) - UNICAMP, Campinas, 2007, p. 55.

36 GOMES, Nilma Lino. O Movimento Negro Educador: saberes construídos nas lutas por emancipação. Rio de Janeiro: Vozes, 2017, p. 51.
} 
refletirdes um momento vereis quão dolorida é a situação da mulher nas fábricas, nas oficinas, constantemente, amesquinhadas por seres repelentes" ${ }^{37}$. Portanto, o feminismo de primeira onda do final do século XIX estava "centrado na reivindicação por direitos políticos - votar e ser eleita -, nos direitos sociais e econômicos - como o trabalho remunerado, estudo, propriedade e herança". ${ }^{38}$

A segunda onda teve como marco inicial a década de 1960, devido a uma confluência de fatores, tais como: a guerra do Vietnã e o surgimento do movimento hippie nos Estados Unidos, - Maio de 68 em Paris, que ressoou em todo universo acadêmico ao longo de toda Europa Ocidental, a insatisfação crescente com a esquerda comunista e as burocracias partidárias, o lançamento da pílula anticoncepcional nos Estados Unidos e na Alemanha, a emergência dos regimes militares na América Latina, o desenvolvimento da teoria feminista. 0 feminismo de segunda onda "surgiu após a Segunda Guerra Mundial e deu prioridade às lutas pelo direito ao corpo, ao prazer e contra o patriarcado - entendido como o poder dos homens na subordinação das mulheres". Foi nesta onda do feminismo que "a categoria gênero foi criada, como tributária das lutas do feminismo e do movimento das mulheres". ${ }^{39}$

As primeiras manifestações feministas no Brasil aconteceram na década de 1970 no ambiente do regime militar, muito limitado pelas condições que o país vivia naquela época. Com a redemocratização dos anos 1980, o feminismo no Brasil entra em uma fase de grande efervescência na luta pelos direitos das mulheres: "há inúmeros grupos e coletivos em todas as regiões tratando de uma gama muito ampla de temas - violência, sexualidade, direito ao trabalho, igualdade no casamento, direito a terra, direito à saúde materno-infantil, luta contra o racismo, opções sexuais". ${ }^{40}$

As mulheres passaram a apontar que além da dominação de classe, há também outra forma de dominação do homem sobre a mulher que não pode ser explicada pela de classe. Nesse sentido, surge o feminismo: “que não quer só espaço para a mulher - no trabalho, na vida pública, na educação -, mas que luta, sim, por uma nova forma de relacionamento entre homens

\footnotetext{
37 PINTO, Céli Regina Jardim. Uma história do feminismo no Brasil. São Paulo: Fundação Perseu Abramo, 2003, p. 35.

${ }^{38}$ PEDRO, Joana Maria. Traduzindo o debate: o uso da categoria de gênero na pesquisa histórica. História , Franca, v. 24, n. 1, p. 77-98, 2005, p. 79.

39 PEDRO, Joana Maria. Traduzindo o debate: o uso da categoria de gênero na pesquisa histórica. História , Franca, v. 24, n. 1, p. 77-98, 2005, p. 79.

40 PINTO, Céli Regina Jardim. Uma história do feminismo no Brasil. São Paulo: Fundação Perseu Abramo, 2003, p. 17.
} 
e mulheres, em que esta última tenha liberdade e autonomia para decidir sobre sua vida e seu corpo". ${ }^{41}$

Frisa-se por oportuno, que o movimento político e social feminista tem por objetivo a emancipação da mulher, a sua libertação de todas as formas de opressão, e o exercício pleno dos seus direitos de cidadania, questionando a hierarquização dos sexos imposta pela sociedade patriarcal e machista.

Todavia, os paradigmas instituídos pelo feminismo, segundo Lélia Gonzalez, apresentam dificuldades para as mulheres negras, sendo uma delas, a inclinação eurocentrista do feminismo brasileiro que:

[...] constitui um eixo articulador a mais da democracia racial e do ideal de branqueamento, ao omitir o caráter central da questão da raça nas hierarquias de gênero e ao universalizar os valores de uma cultura particular (a ocidental) para o conjunto das mulheres, sem mediá-los na base da interação entre brancos e não brancos. ${ }^{42}$

Nessa perspectiva, a exclusão da presença das mulheres negras da história dos movimentos feministas visíveis pode ser analisada como uma estratégia de invisibilizar e de fazer a manutenção da subordinação desses grupos, que servirá ao interesse das mulheres e homens brancos. De certa forma, essa invisibilidade vem sendo benéfica para algumas correntes feministas que não estão de fato engajadas com a alteração do status quo.

As mulheres negras não existem. Ou, falando de outra forma: as mulheres negras, como sujeitos identitários e políticos, são resultado de uma articulação de heterogeneidades, resultante de demandas históricas, políticas, culturais, de enfrentamento das condições adversas estabelecidas pela dominação ocidental eurocêntrica ao longo dos séculos de escravidão, expropriação colonial e da modernidade racializada e racista em que vivemos. ${ }^{43}$

Isso porque segundo bell hooks: "as análises feministas sobre a sina da mulher tendem a se concentrar exclusivamente no gênero, refletem a tendência predominantemente patriarcal e ocidental" 44 , ignorando as mulheres que sofrem opressão de raça ou classe. Enquanto que, as

\footnotetext{
${ }^{41}$ PINTO, Céli Regina Jardim. Uma história do feminismo no Brasil. São Paulo: Fundação Perseu Abramo, 2003, p. 16.

42 CARNEIRO, Sueli. Enegrecer o feminismo: A Situação da Mulher Negra na América Latina a partir de uma perspectiva de gênero. In: Ashoka Empreendimentos Sociais \& Takano Cidadania (Orgs.). Racismos contemporâneos. Rio de Janeiro: Takano Editora, 2011.

${ }^{43}$ WERNECK, Jurema. Nossos passos vêm de longe! Movimentos de mulheres negras e estratégias políticas contra o sexismo e o racismo. Revista da Associação Brasileira de Pesquisadores/as Negros/as (ABPN), [S.l.], v. 1, n. 1, p. 07-17, jun. 2010, p. 11.

44 hooks, bell. Mulheres negras: moldando a teoria feminista. Revista Brasileira de Ciência Política, $\mathrm{n}$. 16, p. 193-210. abr. 2015, p. 15.
} 
feministas socialistas embora se concentrem na classe e gênero, "tendem a negar a raça, ou fazem questão de reconhecer que a raça é importante e, em seguida, continuam apresentando uma análise em que a raça não é considerada", ambas vertentes, desta forma, não proporcionam uma base sólida sobre a qual se deve construir uma teoria feminista que inclua e dê visibilidade às mulheres negras.

No mesmo sentido hooks ${ }^{45}$, afirma que: "os homens negros podem ser vitimados pelo racismo, mas o sexismo os permite atuar como exploradores e opressores das mulheres". Concluindo que:

Como grupo, as mulheres negras estão em uma posição incomum nesta sociedade, pois não só estamos coletivamente na parte inferior da escada do trabalho, mas nossa condição social geral é inferior à de qualquer outro grupo. Ocupando essa posição, suportamos o fardo da opressão machista, racista e classista. ${ }^{46}$

Assim, a mulher negra quando consegue vencer a invisibilidade política e social a que está sujeita no Brasil, ao inserir-se na sociedade sofre com a dupla discriminação de raça e de gênero, com isso não que dizer que a opressão sofrida pela mulher negra seja mais importante do que a sofrida pela mulher branca, contudo, é necessário que haja a compreensão sobre as desvantagens decorrentes da posição social da mulher negra, que é justamente, a de mantê-la no papel de inferior à da mulher branca e ao homem negro.

Ribeiro ${ }^{47}$ esclarece que se para "Simone de Beavoir, a mulher é o Outro por não ter reciprocidade no olhar do homem, para Grada Kilomba, a mulher negra é o Outro do Outro", posição que a coloca num local de mais difícil reciprocidade. Nesse sentido, "o olhar tanto de homens brancos e negros e mulheres brancas confinaria a mulher negra num lugar de subalternidade" que se resume na antítese de branquitude e masculinidade, impedindo que estas sejam vistas como sujeitos.

Por isso, Collins enfatiza a importância das mulheres negras se autodefinirem, a fim de transcender esse status que as constituem em objeto:

A insistência de mulheres negras autodefinirem-se, autoavaliarem-se e a necessidade de uma análise centrada na mulher negra é significativa por duas razões: em primeiro lugar, definir e valorizar a consciência do próprio ponto de vista autodefinido frente a imagens que promovem uma autodefinição sob a

\footnotetext{
45 hooks, bell. Mulheres negras: moldando a teoria feminista. Revista Brasileira de Ciência Política, n. 16, p. 193-210. abr. 2015, p. 15.

${ }^{46}$ hooks, bell. Mulheres negras: moldando a teoria feminista. Revista Brasileira de Ciência Política, n. 16, p. 193-210. abr. 2015, p. 15.

${ }^{47}$ RIBEIRO, Djamila. O que é lugar de fala? Belo Horizonte (MG): Letramento, 2017, p. 40.
} 
FEMINISMO NEGRO NO BRASIL E LUTA POR RECONHECIMENTO: UM DIÁLOGO COM A TEORIA DA JUSTIÇA DE NANCY FRASER

FERNANDA DA SILVA LIMA ANGÉLICA AZEREGO GARCIA CAPORAL

forma de "outro" objetificado é uma forma importante de se resistir à desumanização essencial aos sistemas de dominação. O status de ser o "outro" implica ser o outro em relação a algo ou ser diferente da norma pressuposta de comportamento masculino branco. Nesse modelo, homens brancos poderosos definem-se como sujeitos, os verdadeiros atores, e classificam as pessoas de cor e as mulheres em termos de sua posição em relação a esse eixo branco masculino. Como foi negada às mulheres negras a autoridade de desafiar essas definições, esse modelo consiste de imagens que definem as mulheres negras como um outro negativo, a antítese virtual da imagem positiva dos homens brancos. ${ }^{48}$

Desta forma a luta das mulheres negras pela libertação em nossa sociedade deve abranger todas as formas de opressão, uma vez que não se trata apenas da capacidade de superar as desigualdades geradas pela história hegemônica masculina, mas se exige, ainda, a superação de ideologias complementares desse sistema de opressão, como é o caso do racismo. Para Carneiro:

0 racismo estabelece a inferioridade social dos segmentos negros da população em geral e das mulheres negras em particular, operando ademais como fator de divisão na luta das mulheres pelos privilégios que se instituem para as mulheres brancas. Nessa perspectiva, a luta das mulheres negras contra a opressão de gênero e de raça vem desenhando novos contornos para a ação política feminista e anti-racista, enriquecendo tanto a discussão da questão racial, como a questão de gênero na sociedade brasileira. ${ }^{49}$

À vista disso, a integração do olhar feminista com o antirracista, englobando as lutas tradicionais do movimento negro com a tradição de luta do movimento das mulheres, afirma a condição específica da nova identidade política que é a mulher negra.

Núbia Regina Moreira defende a ideia de que o movimento feminista negro é fruto de uma intersecção entre os movimentos negro e feminista. Afirma a autora que atualmente o movimento negro não pode desconsiderar a questão do gênero assim como o movimento feminista não pode desconsiderar a questão da raça. Então se possibilita através das lutas do feminismo negro a "generificação da raça" e a "racialização do gênero". Para perceber em que medida raça, classe e gênero estão interligados por sistemas de opressões caracterizando o sujeito identitário específico que é a mulher negra. ${ }^{50}$

48 COLLINS, Patricia Hill. Aprendendo com a outsider within: a significação sociológica do pensamento feminista negro. Revista Sociedade e Estado. [online]. 2016, vol.31, n.1 [cited 2019-02-18], p. 105.

${ }^{49}$ CARNEIRO, Sueli. Enegrecer o feminismo: A Situação da Mulher Negra na América Latina a partir de uma perspectiva de gênero. In: Ashoka Empreendimentos Sociais \& Takano Cidadania (Orgs.). Racismos contemporâneos. Rio de Janeiro: Takano Editora, 2011.

${ }^{50}$ MOREIRA, Núbia Regina. Movimento feminista negro no Brasil. 2018. Disponível em: <https://www.youtube.com/watch?v=TQa0La1YlFw> Acesso em: 08/11/2018. 
O movimento feminista negro luta contra a categoria universal mulher, que utilizada como bandeira de luta pelo movimento feminista, representava a mulher branca de classe média em sua maioria, invisibilizando as de outras classes sociais e de outras "raças". Para o movimento feminista negro, a mulher negra deve ser abordada como categoria situada em suas relações, tendo em vista que o racismo não escolhe classe social, assim como o sexismo também não escolhe. As relações de hierarquia estão presentes entre homem e mulher, entre mulheres, entre mulher branca e mulher negra, entre mulheres negras inclusive.

Segundo Bairros a alternativa mais recente de transformar a categoria mulher, experiência política e pessoal é:

[...] o ponto de vista feminista (ferninist standpoint). Segundo essa teoria a experiência da opressão sexista e dada pela posição que ocupamos numa matriz de dominação onde raça gênero e classe social interceptam-se em diferentes pontos. Assim uma mulher negra trabalhadora não é triplamente oprimida ou mais oprimida do que uma mulher branca na mesma classe social mas experimenta a opressão a partir de um lugar que proporciona um ponto de vista diferente sobre o que é ser mulher numa sociedade desigual racista e sexista. Raça, gênero, classe social, orientação sexual reconfiguram-se mutuamente formando o que Grant chama de um mosaico que só pode ser entendido em sua multidimensionalidade. De acordo com o ponto de vista feminista portanto não existe uma identidade una pois a experiência de ser mulher se dá de forma social e historicamente determinadas. ${ }^{51}$

Essa formulação é importante porque ajuda a entender diferentes formas de feminismos e permite pensar em termos de movimento negro e de mulheres negras no Brasil. Revelando as tensões existentes dentro dos movimentos negros e feministas em relação à mulher negra. Denuncia a necessidade de se dar expressão a diferentes formas de ser negra - vivida através do gênero, e de ser mulher - vivida através da raça, o que torna supérflua a discussão sobre qual opressão as mulheres negras deveriam lutar: as racistas ou as sexistas.

Segundo Moreira:

A tensão entre o movimento das mulheres negras e o feminismo, "que faz uma leitura do cotidiano e do imaginário das mulheres de classe média", é contemporânea à crítica ao modelo de identidade feminina universal e abstrata que se instaura no interior do feminismo mediante as vozes de outras mulheres que não se sentiam representadas por esta identidade. ${ }^{52}$

\footnotetext{
51 BAIRROS, Luiza. Nossos feminismos revisitados. Revista Estudos Feministas/Dossiê Mulheres negras. Rio de Janeiro:IFC/UFRJ,3(2):458. 1995, p. 461.

52 MOREIRA, Núbia Regina. O feminismo negro brasileiro: um estudo dos movimentos de mulheres negras no Rio de Janeiro e São Paulo. (Dissertação) Mestrado em Sociologia pela Universidade Estadual de Campinas/SP, 2007, p. 62.
} 
Já no que se refere à tensão entre o movimento das mulheres negras e o movimento negro Bairros explica que:

O enfrentamento com o poder e o machismo se dá principalmente a partir das nossas relações com os militantes homens dentro do Movimento Negro do que propriamente por um questionamento das relações que cada uma de nós possa ter com seus companheiros. Desse modo vamos começando a identificar uma distância entre o discurso dos homens negros militantes, que em geral é um discurso de exaltação à mulher negra, a sua prática que é de confinamento da mulher militante ao "tarefismo", à ausência da representatividade efetiva nas instâncias de direção do Movimento Negro. Nesse ponto instala-se uma disputa surda, onde o homem negro vê a mulher negra militante como alguém que concorre com ele dentro de um espaço que ele julgava a salvo de qualquer obstáculo, obstáculos do mesmo tipo com que ele se defronta dentro da sociedade abrangente, dentro da sociedade branca, digamos assim. ${ }^{53}$

Por consequência, o feminismo negro "ao trazer para a cena política as contradições resultantes da articulação das variáveis de raça, classe e gênero, promove a síntese das bandeiras de luta historicamente levantadas pelos movimentos negros e de mulheres do país", esta integração entre os diversos movimentos, "engrandece de um lado, as reivindicações das mulheres, tornando-as assim mais representativas do conjunto das mulheres brasileiras, e, por outro lado, promovendo a feminização das propostas e reivindicações do movimento negro". ${ }^{54}$

Isso porque as mulheres negras não podem escolher contra qual opressão lutar, a discriminação de raça ou a discriminação de gênero, ambas se entrecruzando com a de classe, todas são igualmente importantes para emancipação dessas mulheres. Essas categorias devem ser ampliadas para que se possa entender a multiplicidade de opressões que as mulheres negras enfrentam. Enquanto a discriminação de gênero diz respeito às mulheres, a racial diz respeito à raça, os movimentos sociais negros e feministas buscam lutar contra um tipo específico de opressão, das quais as mulheres negras muitas vezes são excluídas se tornando invisíveis dentro destes movimentos, uma vez que seus problemas são subincluídos e não vão para agenda desses movimentos como se suas demandas não merecessem ser discutidas.

Nessa lógica afirma Collins:

0 que temos agora é uma crescente sofisticação sobre como discutir localização de grupo, não no quadro singular de classe social proposto por Marx, nem nos mais recentes enquadramentos feministas que defendem a primazia de gênero,

\footnotetext{
53 BAIRROS, Luiza. A Mulher Negra e o Feminismo. In: O Feminismo do Brasil: reflexões teóricas e perspectivas. Ana Alice Alcantara Costa, Cecília Maria B. Sardenberg, organizadoras. Salvador: UFBA / Núcleo de Estudos Interdisciplinares sobre a Mulher, 2008, p. 140-141.

${ }^{54}$ CARNEIRO, Sueli. Enegrecer o feminismo: A Situação da Mulher Negra na América Latina a partir de uma perspectiva de gênero. In: Ashoka Empreendimentos Sociais \& Takano Cidadania (Orgs.). Racismos contemporâneos. Rio de Janeiro: Takano Editora, 2011.
} 
mas dentro de construções múltiplas residentes nas próprias estruturas sociais e não em mulheres individuais. ${ }^{55}$

As experiências das mulheres negras como grupo localizado de forma socialmente hierarquizada e não humanizada faz com que as produções intelectuais, saberes e vozes sejam tratados de forma igualmente subalternizado, além das condições sociais as manterem num lugar silenciado estruturalmente. Por essa perspectiva, a luta do movimento feminista negro é principalmente pela libertação da mulher negra a qual foi reservado no imaginário brasileiro um lugar negativo de "corpo sem mente".

À mulher negra no cenário brasileiro são atribuídas - segundo a obra de Gilberto Freyre, Casa Grande e Senzala - dois papeis (hierarquizados): à mulata, um ser-corpo sexualizado pronto para satisfazer os desejos sexuais dos outros; e à negra, um ser-corpo trabalho, o servilismo tem sido considerado atributo natural ou papel social designativo das funções de mulher negra na sociedade. ${ }^{56}$

Nesse sentido, as mulheres negras que “[...] lutavam nas irmandades criadas no período logo após a escravidão, na Frente Negra Brasileira, na década de 1930", foram excluídas dos relatórios da história política brasileira e mundial, e da história do feminismo, como parte das estratégias de invisibilização e subordinação desses grupos, perpetradas pelos grupos hegemônicos que pretendem reordenar a história de acordo com os interesses dos homens e mulheres brancas, fazendo permanecer no imaginário brasileiro os estereótipos atribuídos por Freyre de objetificação das mulheres negras. ${ }^{57}$

Assim, tem-se que o feminismo negro é antes de tudo um movimento pelo reconhecimento da mulher negra como um sujeito identitário e político que por suas peculiaridades de raça não deve ser assimilada pelo movimento negro, e que por suas peculiaridades de gênero não deve ser assimilada pelo movimento feminista branco. Deve-se sim, buscar uma forma de interação com tais movimentos para unirem forças nas suas reivindicações comuns, sem perder de vista o respeito pelas diferenças de forma a não cair na armadilha da invisibilidade.

\footnotetext{
${ }^{55}$ COLLINS, Patricia Hill. Comment on Hekman's "Truth and Method: Feminist Standpoint Theory Revisited": Where's the Power? Signs, v. 22, n. 2, p.375-381, 1997.

${ }^{56}$ MOREIRA, Núbia Regina. 0 feminismo negro brasileiro: um estudo dos movimentos de mulheres negras no Rio de Janeiro e São Paulo. (Dissertação) Mestrado em Sociologia pela Universidade Estadual de Campinas/SP, 2007, p. 18-19.

57 WERNECK, Jurema. Nossos passos vêm de longe! Movimentos de mulheres negras e estratégias políticas contra o sexismo e o racismo. Revista da Associação Brasileira de Pesquisadores/as Negros/as (ABPN), [S.l.], v. 1, n. 1, p. 07-17, jun. 2010, p. 15-16.
} 
FEMINISMO NEGRO NO BRASIL E LUTA POR RECONHECIMENTO: UM DIÁLOGO COM A TEORIA DA JUSTIÇA DE NANCY FRASER

FERNANDA DA SILVA LIMA ANGÉLICA AZEREGO GARCIA CAPORAL

A ideia não é mais a compreensão das diferenças culturais pela via assimilacionista, uma vez que esta é negadora do reconhecimento e da valorização das identidades, mas sim a efetivação da igualdade material pela perspectiva crítica da sociedade atual que pode utilizar as teorias políticas sobre reconhecimento para designar um novo parâmetro normativo de justiça.

\section{REDISTRIBUIÇÃO OU RECONHECIMENTO?}

Consideradas as diferenças interculturais que compõem a sociedade brasileira, Santos indica que o novo caminho, para romper com os processos de exclusão e desigualdades, será repensar a política de igualdade articulada com as políticas de identidade, segundo afirmou no seguinte enunciado: "temos o direito a ser iguais sempre que a diferença nos inferioriza; temos o do direito a ser diferentes sempre que a igualdade nos descaracteriza". ${ }^{58}$

A teoria valorativa do princípio da igualdade reconhece ser imprescindível que o ideal de igualdade corresponda à garantia de justiça social, aliada com a concepção de uma justiça redistributiva, orientada muitas vezes pelo critério econômico, e que possibilite combater o binômio desigualdade-exclusão. E também que a interpretação do princípio da igualdade esteja alinhada com o constitucionalismo democrático, e no caso brasileiro impõe que o Sistema de Justiça alcance a interpretação da cláusula da igualdade, almejando maiores possibilidades quanto à redistribuição de direitos, em consonância com os fundamentos e objetivos da República Federativa do Brasil. ${ }^{59}$

Ainda que se prefira o termo interculturalidade ${ }^{60}$ no lugar de multiculturalismo, pode-se também tecer considerações acerca do que representa na teoria social o multiculturalismo de

\footnotetext{
58 SANTOS, Boaventura de Sousa. A gramática do tempo: para uma nova cultura política. São Paulo: Cortez, 2006. (Col. Para um novo senso comum, v. 4)

59 FRISCHEISEN, Luiza Cristina Fonseca. A construção da igualdade e o sistema de justiça no Brasil: alguns caminhos e possibilidades. Rio de Janeiro: Lumen Juris, 2007, p. 10.

60 Flores argumenta a preferência pelo termo interculturalidade no lugar de multiculturalismo por compreender que "[...] os problemas culturais estão estritamente interconectados com os problemas políticos e econômicos. A cultura não é uma entidade alheia ou separada das estratégias de ação social; ao contrário, é uma resposta, uma reação à forma como se constituem e se desenvolvem as relações sociais, econômicas e políticas em um tempo e um espaço determinados." FLORES, Joaquín Herrera. Direitos Humanos, interculturalidade e racionalidade de resistência. Seqüência, Florianópolis, UFSC, v. 23, n. 44, 2002, p. 12. Da mesma forma Catherine Walsh desenvolve um argumento crítico acerca de sua preferência ao termo interculturalidade em sentido crítico. Para a autora: "[...] a interculturalidade crítica tem suas raízes e antecedentes não no Estado (nem na academia), mas nas discussões políticas postas em cena pelos movimentos sociais, faz ressaltar seu sentido contra-hegemônico, sua orientação com relação ao problema estrutural-colonial-capitalista e sua ação de transformação e criação." Propõe portanto Walsh "[...] a interculturalidade crítica como ferramenta pedagógica que questiona continuamente a racialização, subalternização, inferiorização e seus padrões de poder, visibiliza maneiras diferentes de ser, viver e saber e busca o desenvolvimento e criação de compreensões e condições que
} 
FERNANDA DA SILVA LIMA ANGÉLICA AZEREGO GARCIA CAPORAL

tendência conservadora criticado tanto por Boaventura de Sousa Santos quanto por Herrera Flores. O multiculturalismo de tendência conservadora, embora reconheça a pluralidade e a diversidade culturais presentes na sociedade, é incapaz de possibilitar uma visão que fuja à lógica de um universalismo abstrato, pois parte da ideia, de forma exemplificativa, de que se existem desigualdades entre pessoas, as políticas de ação afirmativa - neste caso as políticas de redistribuição - seriam suficientes para sanar as desigualdades e os possíveis conflitos entre os grupos.

Assim, compreender as relações raciais no Brasil, a partir da concepção do multiculturalismo de matriz conservadora - com investimento em ações afirmativas - pode potencializar processos de subordinação e dominação de alguns grupos em detrimento de outros, um se sobrepõe ao outro, mantendo-se a estrutura hierárquica na sociedade - Ex: os negros em relação de subordinação aos brancos.

Assim descreve Flores (2002, p. 20):

[...] existem muitas culturas, mas somente uma pode considerar-se o padrão ouro do universal. Por sua parte, a visão localista nos conduzirá a um multiculturalismo liberal de tendência progressista: todas as culturas são iguais, não há mais que se estabelecer um sistema de quotas ou de afirmative action, para que as "inferiores" ou "patológicas" possam aproximar-se à hegemonia, mas, ao estilo do politicamente correto, respeitando sempre a hierarquia dominante. Outorgar voz e presença, em razão das diferentes posições sociais, é uma forma de ocultar a "diferença"; em muitas ocasiões, não é mais que uma conseqüência das desigualdades que ocorrem, no início, ou bem no desenvolvimento do processo de relações sociais. ${ }^{61}$

Embora as políticas de ação afirmativa sejam ferramentas importantes no campo das políticas públicas, para pôr em equilíbrio os diferentes grupos raciais, ou ainda, promover uma igualdade racial, estas políticas, na visão de Flores $^{62}$, seriam mecanismos insuficientes para

não só articulam e fazem dialogar as diferenças num marco de legitimidade, dignidade, igualdade, equidade e respeito, mas que - ao mesmo tempo - alentam a criação de modos "outros" - de pensar, ser, estar, aprender, ensinar, sonhar e viver que cruzam fronteiras." Concordamos com ela quando pensamos este artigo a partir da perspectiva de luta das mulheres negras e a sua posição social enquanto sujeito invisível e subalterno. A interculturalidade é ferramenta de resistência e indica uma nova pedagogia, pedagogia de-colonial, pois rompe não só com o eurocentrismo, mas com as estrututuras estabelecidas a partir da colonialidade do poder, ser e saber. WALSH, Catherine. Interculturalidade Crítica e Pedagogia Decolonial: in-surgir, re-existir e re-viver. In: CANDAU, Vera Maria. (org) Educação Intercultural na América Latina: entre concepções, tensões e propostas. Rio de Janeiro: 7 Letras, 2009, p. 25.

61 FLORES, Joaquín Herrera. Direitos Humanos, interculturalidade e racionalidade de resistência. Sequiência, Florianópolis, UFSC, v. 23, n. 44, 2002, p. 20.

62 FLORES, Joaquín Herrera. Direitos Humanos, interculturalidade e racionalidade de resistência. Seqüência, Florianópolis, UFSC, v. 23, n. 44, 2002, p. 12. 
superar a lógica de dominação e subordinação imposta aos grupos (negros), neste caso, às mulheres negras, receptoras de tais políticas.

Por isso, o movimento intercultural se baseia “[...] no reconhecimento da diferença e do direito à diferença e da coexistência ou construção de uma vida em comum além de diferenças de vários tipos." ${ }^{63}$ A concepção intercultural de direitos humanos fundamenta-se na retomada crítica do pensamento ocidental como contraponto da concepção universalista, que permite, de fato, assegurar um mundo comum sob os anseios da pluralidade e da diversidade entre os indivíduos ${ }^{64}$. "O respeito, a preservação e a promoção das culturas dos grupos minoritários convertem-se assim numa das dimensões fundamentais do princípio da igualdade.” ${ }^{\circ 5}$

A luta pela igualdade racial e a luta das mulheres negras no Brasil não podem ser uma fórmula vazia, ou basear-se apenas em sistemas numéricos, como os sistemas de quotas (ações afirmativas), mas deve prevalecer o entendimento de que é fundamental o reconhecimento das identidades e o respeito pelo diferente. E ao mesmo tempo falar sobre igualdade não implica homogeneização forçada, pois todos devem ter igual liberdade de ser diferente e de viver de forma plena de acordo com essas diferenças ${ }^{66}$.

Em razão disto é que surgem novas teorizações acerca do direito à diferença e a luta contra as desigualdades provenientes destas. Trata-se da política do reconhecimento amparada na ideia de promoção de justiça social. Não se tenta mais compreender as diferenças culturais pela via assimilacionista, pois esta, como se sabe, é negadora do reconhecimento e da valorização das identidades e, em razão disto, propulsora da manutenção da dicotomia dominadores/dominados, pois haveria sempre a prevalência de uma cultura em detrimento de outra, à qual se atribuiria o status de superior ou dominante.

Fraser ${ }^{67}$ aponta novos caminhos que conduzem à percepção de justiça social. Se antes as demandas por justiça social baseavam-se tão somente em políticas redistributivas, agora cede-se

\footnotetext{
${ }^{63}$ SANTOS, Boaventura de Sousa. Por uma concepção multicultural de direitos humanos. In: (Org.). Reconhecer para libertar: os caminhos do cosmopolitismo multicultural. Rio de Janeiro: Civilização Brasileira, 2003b. (Coleção Reinventar a Emancipação Social: para novos manifestos. v. 3), p. 33.

${ }^{64}$ LAFER, Celso. A reconstrução dos direitos humanos: a contribuição de Hannah Arendt. Estudos Avançados, São Paulo, v. 11, n. 30, 1997, p. 56.

65 SARMENTO, Daniel. Direito Constitucional e Igualdade Étnico-Racial. In: SOUZA, Douglas Martins; PIOVESAN, Flávia (Coords.). Ordem Jurídica e Igualdade Étnico-Racial. Rio de Janeiro: Lumen Juris, 2008, p. 68.

66 SARMENTO, Daniel. Direito Constitucional e Igualdade Étnico-Racial. In: SOUZA, Douglas Martins; PIOVESAN, Flávia (Coords.). Ordem Jurídica e Igualdade Étnico-Racial. Rio de Janeiro: Lumen Juris, 2008, p. 69.

67 FRASER, Nancy. Redistribuição, Reconhecimento e Participação: Por uma Concepção Integrada da Justiça. In: SARMENTO, Daniel; IKAWA, Daniela; PIOVESAN, Flávia (Coords.). Igualdade, Diferença e Direitos Humanos. Rio de Janeiro: Lumen Juris, 2008, p. 167-168.
} 
o espaço também para a construção da justiça social voltada para as demandas por reconhecimento, reconhecimento de identidades, reconhecimento do outro, da outra. Para a autora, em universos desiguais, lutar por políticas de redistribuição e por políticas de reconhecimento de forma separada ou antagônica, não representa mais do que uma falsa antítese.Para ela nenhuma das duas teses é suficiente para responder às demandas por justiça social. Por isso, a base da teoria da autora se sustenta em construir uma orientação políticoprogramática capaz de integrar o melhor da política de redistribuição com o melhor da política de reconhecimento da diferença.

As políticas de redistribuição e de reconhecimento se diferem em pelo menos três situações pontuais. A primeira delas relaciona-se com o fato de as duas políticas abordarem concepções diferenciadas de injustiça, uma vez que a política de redistribuição dá ênfase no combate às injustiças de ordem socioeconômica, enquanto a política de reconhecimento centrase nas injustiças de ordem cultural, e estão enraizadas nos padrões sociais de representação, geradores de dominação cultural (por aquela de status predominante), de não reconhecimento de identidades e de desrespeito.

Em segundo lugar, o que diferencia uma política da outra é a estratégia que cada uma adota para resolver o problema da injustiça social. Enquanto a política de redistribuição investe numa reestruturação político-econômica (programas de transferência de renda são exemplo), a política de reconhecimento aposta que o remédio para enfrentar a injustiça social é a transformação cultural, o respeito e a valorização das identidades consideradas até então subalternas. Há uma aposta na diversidade cultural nas políticas de reconhecimento. E em terceiro lugar, as duas políticas são direcionadas para grupos diferentes, a política de redistribuição atenderia aos grupos injustiçados em razão de sua classe social, já a do reconhecimento atende aquele grupo que, dada a sua cultura, apresenta baixo status, visto pelo padrão cultural como diferente e, portanto, possui baixo prestígio social ${ }^{68}$.

O enfrentamento da discussão racial e da luta por reconhecimento das mulheres negras no Brasil deve perpassar pelo investimento nestas duas políticas: de redistribuição e de reconhecimento, pois, como se viu, não são, na concepção de Fraser ${ }^{69}$, antagônicas. Assim, a luta pela igualdade racial deve estar pautada pela melhoria das condições de trabalho das

68 FRASER, Nancy. Redistribuição, Reconhecimento e Participação: Por uma Concepção Integrada da Justiça. In: SARMENTO, Daniel; IKAWA, Daniela; PIOVESAN, Flávia (Coords.). Igualdade, Diferença e Direitos Humanos. Rio de Janeiro: Lumen Juris, 2008, p. 169-171.

69 FRASER, Nancy. Redistribuição, Reconhecimento e Participação: Por uma Concepção Integrada da Justiça. In: SARMENTO, Daniel; IKAWA, Daniela; PIOVESAN, Flávia (Coords.). Igualdade, Diferença e Direitos Humanos. Rio de Janeiro: Lumen Juris, 2008, p. 169-171. 
FEMINISMO NEGRO NO BRASIL E LUTA POR RECONHECIMENTO: UM DIÁLOGO COM A TEORIA DA JUSTIÇA DE NANCY FRASER

FERNANDA DA SILVA LIMA ANGÉLICA AZEREGO GARCIA CAPORAL

pessoas negras em equivalência às condições de trabalhos ocupados por brancos e, ao mesmo tempo, travar uma luta contra o eurocentrismo e enfatizar as especificidades da cultura negra, de forma a valorizá-la. A dificuldade parece estar em como conciliar a igualdade e a diferença, pois a política de redistribuição busca alcançar uma isonomia substantiva entre os diferentes grupos raciais, enquanto a política de reconhecimento ressalta o valor da 'diferença'. ${ }^{70}$

Essa dificuldade é superada na medida em que Fraser introduz o modelo de "status" segundo o qual o não reconhecimento aparece quando as instituições estruturam a interação dos atores sociais de acordo com normas culturais que impede a paridade de participação. Para a autora o reconhecimento é uma questão de moralidade de busca do correto, assim todos têm igual direito a buscar estima social sob condições justas de igualdade de oportunidades, independentemente da identidade específica do grupo.

Nesse sentido, é injusto que a alguns grupos seja negada a condição de parceiros integrais na interação social, simplesmente em virtude de padrões institucionalizados de valoração cultural de cujas construções eles não participaram em condições de igualdade, e os quais depreciam as suas características distintivas as quais the são atribuídas. Por conseguinte, o não reconhecimento é errado porque constitui uma forma de subordinação institucionalizada e, portanto uma violação da justiça. ${ }^{71}$

Assim, a isonomia substantiva para autora está na igualdade de oportunidades para participar da vida social e política a fim de se criar termos justos para interação sob as condições de pluralismo valorativo que respeite as diferenças, ou seja, evita-se a visão de caráter valorativo de que todos têm direito a igual estima social e se aceita a imposição de respeitar a todos de modo igual ${ }^{72}$, na medida em que têm igual direito de buscar a estima social sob condições justas de igualdade de oportunidades.

\footnotetext{
70 MATTOS, Patrícia de Castro. A sociologia política do reconhecimento: as contribuições de Charles Taylor, Axel Honneth e Nancy Fraser. São Paulo: Annablume, 2006, p. 144.

71 FRASER, Nancy. Reconhecimento sem ética ? Lua Nova, São Paulo, n. 70, p. 101-138, 2007, p. 112.

72 Respeitar a todos de forma igual, segundo BARALDI e PERUZZO, é o primeiro passo para o enraizamento de práticas democráticas participativas como uma forma de garantia e promoção de direitos humanos de minorias em contextos plurais significa compreender a importância da interculturalidade, assim entendida a situação em que a coexistência tolerante e assimilacionista do multiculturalismo vai ceder espaço para a convivểncia respeitosa. Para isso, são imprescindíveis as políticas públicas de combate ao preconceito e à discriminação, bem como as políticas de educação que não apenas permita o respeito pelas diferenças, mas que emancipe as minorias para lutar e promover autonomamente o direito às diferenças. Daí a importância dos movimento sociais como educadores na emancipação dos sujeitos sociais. Cf: BARALDI, Camila Bibiana Freitas; PERUZZO, Pedro Pulzatto. DEMOCRACIA E DIREITOS HUMANOS: A PARTICIPAÇÃO SOCIAL DAS MINORIAS. Revista Eletrônica do Curso de Direito da UFSM, Santa Maria, RS, v. 10, n. 1, p. 347-370, out. 2015, p. 354.
} 
FEMINISMO NEGRO NO BRASIL E LUTA POR RECONHECIMENTO: UM DIÁLOGO COM A TEORIA DA JUSTIÇA DE NANCY FRASER

FERNANDA DA SILVA LIMA ANGÉLICA AZEREGO GARCIA CAPORAL

Logo, para combater as injustiças sofridas pelos vários modelos de sujeitos coletivos situando-se aqui as mulheres negras -, no intuito de se efetivar a justiça social, devem-se gerar mecanismos que busquem satisfazer tanto a redistribuição quanto o reconhecimento. Um desses mecanismos, que possibilita a interação dos vários sujeitos sociais sem que um seja sobreposto ao outro, é o princípio da paridade de participação, segundo o qual: “a justiça requer arranjos sociais que permitam a todos os membros adultos da sociedade, interagirem, uns como outros, como pares". ${ }^{73}$

Todavia, para que esta participação seja possível, pelo menos duas condições devem ser satisfeitas:

Primeiro, a distribuição de recursos materiais deve ser tal que garanta a independência e "voz" aos participantes. [...] a segunda condição intersubjetiva requer que os padrões institucionalizados de valor cultural expressem igual respeito por todos os participantes e assegurem igual oportunidade para a conquista da estima social. ${ }^{74}$

A primeira condição é objetiva e visa combater a desigualdade material, a dependência econômica, busca a justiça distributiva. A segunda visa combater a hierarquia de "status" culturalmente definida, busca a justiça pelo reconhecimento. Nesse sentido, para que ocorra a real paridade participativa, é preciso socializar os bens materiais pela transformação da política econômica; é preciso também desconstruir os padrões de avaliação e interpretações culturais, e ainda transformar toda a estrutura cultural-valorativa que constitui alguns grupos como inferiores a outros.

Essa compreensão torna-se especialmente importante, diante daqueles sujeitos que sofrem injustiças múltiplas, geradas pela interseccionalidade ${ }^{75}$ de opressões, como no caso das

\footnotetext{
${ }^{73}$ FRASER, Nancy. Redistribuição, Reconhecimento e Participação: Por uma Concepção Integrada da Justiça. In: SARMENTO, Daniel; IKAWA, Daniela; PIOVESAN, Flávia (Coords.). Igualdade, Diferença e Direitos Humanos. Rio de Janeiro: Lumen Juris, 2008, p. 181.

74 FRASER, Nancy. Redistribuição, Reconhecimento e Participação: Por uma Concepção Integrada da Justiça. In: SARMENTO, Daniel; IKAWA, Daniela; PIOVESAN, Flávia (Coords.). Igualdade, Diferença e Direitos Humanos. Rio de Janeiro: Lumen Juris, 2008, p. 181

75 O conceito de "interseccionalidade" foi cunhado por Kimberlé Williams Crenshaw. Esta mulher é uma feminista negra norte-americana e professora especializada nas questões de raça e de gênero. Ela usou este termo pela primeira vez numa pesquisa em 1991 sobre as violências vividas pelas mulheres de cores nas classes desfavorecidas nos Estados Unidos. Kimberlé Crenshaw define a interseccionalidade como "formas de capturar as consequências da interação entre duas ou mais formas de subordinação: sexismo, racismo, patriarcalismo." Então, a interseccionalidade tenta estudar não só o fato de ser mulher, estuda ao mesmo tempo o fato de ser negra, ser LGBT (lésbicas, gays, bissexuais, travestis, transexuais e transgênero), etc. Na verdade, segundo Kimberlé Crenshaw, frequentemente o fato de ser mulher racializada é relacionado à classe e ao gênero. Cf: CRENSHAW, Kimberlé. Documento para o encontro de especialistas em aspectos da discriminação racial relativos ao gênero. Estudos Feministas. Florianópolis, ano 10, n. 1, p. 171-188, jan./jun. 2002.
} 
mulheres negras, em que se entrecruzam as opressões de raça, de classe e de gênero (e até mesmo outras), caso em que serão necessárias lutas múltiplas, e que entrecruzam esses diversos fatores.

As mulheres negras, considerando o lugar hierarquizado e não humanizado de dupla subordinação que ocupam na sociedade não conseguem preencher a condição objetiva por tratar-se da classe explorada de trabalhadoras cabendo a elas os trabalhos braçais e pouco remunerados, e nem a intersubjetiva por serem silenciadas estruturalmente e invisibilizadas fazendo com que seus saberes e vozes não sejam ouvidos, por elas não se têm respeito e seu corpo é visto como hipersexualizado, objetificado, sendo a elas atribuída culturalmente a pecha de "corpo sem mente".

Fraser vê as reivindicações por reconhecimento da diferença de forma pragmática e contextualizada, como resposta remediadora para as injustiças específicas pré-existentes, colocando questões de justiça em posição central, ela entende que as necessidades por reconhecimento de atores subordinados diferem das de autores dominantes e que apenas aquelas reivindicações que promovam a paridade de participação são moralmente justificadas. Quais pessoas precisarão de quais tipos de reconhecimento e em quais contextos dependerá da natureza dos obstáculos que elas encontrarão em relação à paridade participativa.

Assim é que a justiça pode requerer o reconhecimento das particularidades - diferenças - em alguns casos como os da categoria híbrida que combina características do tipo ideal de classe explorada com características do tipo ideal da sexualidade desprezada, a qual Fraser denomina de coletividade bivalente:

Grupos subordinados bivalentes sofrem tanto com a má distribuição quanto com o não-reconhecimento, de tal forma que nenhuma dessas injustiças é um efeito direto da outra, mas são ambas primárias e co-originárias. No caso delas, assim, nem uma política de redistribuição sozinha, nem uma política de reconhecimento sozinha bastará. Grupos subordinados bivalentes necessitam de ambas. ${ }^{76}$

Nesse sentido, a teoria da justiça de Fraser é peculiarmente importante para as mulheres negras na medida em que revela o lugar desafiador que estruturalmente ocupam na sociedade ao categorizar a coletividade subordinada bivalente, demonstrando a necessidade de se reparar as injustiças interligadas de má distribuição e não reconhecimento, sofridas cotidianamente por aquelas frente: aos homens brancos dos quais são a antítese negativa, as

76 FRASER, Nancy. Redistribuição, Reconhecimento e Participação: Por uma Concepção Integrada da Justiça. In: SARMENTO, Daniel; IKAWA, Daniela; PIOVESAN, Flávia (Coords.). Igualdade, Diferença e Direitos Humanos. Rio de Janeiro: Lumen Juris, 2008, p. 176. 
mulheres brancas que defendem uma categoria universal de mulher representando no movimento feminista as brancas de classe média, e aos homens negros que lutam contra o racismo, porém relegam as mulheres negras dentro do movimento tarefas de menos importância.

Por fim, buscou-se por meio do diálogo com a teoria crítica do reconhecimento de Nancy Fraser, encontrar novas estratégias que contribuam com a luta das mulheres negras e a construção do feminismo negro enquanto campo teórico emergente. Chegando-se a conclusão de que por meio do modelo teórico proposto pela autora, calcado no dualismo de perspectiva, a estratégia utilizada pelo movimento feminista negro, para dar visibilidade à mulher negra, a fim de resguardar seus direitos, deve voltar-se para a eliminação dos valores culturais institucionalizados que impedem a minoria - denominada pela autora, neste caso, de coletividade bivalente -, de interagirem na vida social, inviabilizando a participação paritária.

Diante dessa revelação a autora contribui com o pensamento feminista negro sobre a importância de dialogar com outros sujeitos coletivos tais como o movimento negro e o movimento feminista, a fim de incluírem em suas agendas lutas que combatam as ideologias complementares do sistema de opressão que invisibilizam as mulheres negras, para que todos, interagindo como pares unam suas forças na reivindicação de políticas de redistribuição e de reconhecimento capazes de transformar as mulheres negras no sujeito político identitário que, representadas pelo movimento feminista negro, alçaram participação paritária para participarem da construção de um novo parâmetro normativo de justiça social, que promova a igualdade material com respeito pelas diferenças e igual direito a todas e todos de buscar a estima social sob condições justas de igualdade de oportunidades.

\section{CONCLUSÃO}

Abordar as diferenças e as desigualdades no mundo contemporâneo é tarefa extremamente complexa, uma vez que as diferenças poderão ser reconhecidas ou negadas, e ao mesmo tempo as desigualdades podem ser contestadas ou sofridas de forma passiva. A valorização e o resgate das diferenças se apresentam como instrumental imprescindível na luta contra as desigualdades que se constituem a partir da negação das diferenças. Pode-se falar em desigualdades de gênero, raça, idade, nacionalidade e tantas outras.

É urgente ressignificar a própria concepção de universalidade dos direitos humanos. Espera-se que a universalidade ressignificada seja capaz de contemplar a proteção de sujeitos 
vulneráveis, tais como as mulheres, crianças e adolescentes, negros, deficientes, homossexuais, entre outros.

É imprescindível desvencilhar a teoria dos direitos humanos dos velhos resquícios eurocêntricos, cuja simbologia sempre se apresentou como um verdadeiro obstáculo à consolidação dos direitos humanos de fato, seja porque sempre procurou a manutenção de um status quo insensível aos direitos dos grupos subalternos - incluindo neste estudo as mulheres negras - seja como barreira instrumental de processos de luta e processos políticos de luta por direitos.

Para as mulheres negras as lutas são ainda mais desafiadoras porque precisam vencer a invisibilidade dentro dos movimentos sociais: negro e feminista, para que possam ser vistas como atoras sociais diferenciadas e particularizadas que sofrem opressões múltiplas, de maneira a afirmar a identidade do movimento feminista negro como sujeito coletivo político engajado na emancipação das mulheres negras.

A teoria do reconhecimento proposta por Nancy Fraser confere caminhos para a reconstrução de uma sociedade mais justa e igual por meio do modelo de "status" que envolve a paridade de participação. Esclarece que para tanto todos e todas devem estar representados e agir como pares neste processo de definição e criação de normas que permitam interagir de forma justa sob as condições do pluralismo valorativo. Assim, critica o padrão cultural universal institucionalizado que nega a alguns indivíduos e especialmente as mulheres negras a qualidade de sujeitos políticos identitários com autoridade para desafiar as definições impostas pelo colonialismo, indo ao encontro do pensamento intercultural e decolonial que buscam outras formas de poder, ser e saber, a fim de emancipar estas atoras sociais.

Para tanto, segundo Nancy Fraser, é preciso uma conscientização de que o local em que as mulheres negras estão inseridas na sociedade é de dupla subordinação fazendo parte da categoria denominada coletividade bivalente, para que suas lutas pela emancipação envolvam tanto políticas de redistribuição quanto políticas de reconhecimento, a fim de que possam ultrapassar o silenciamento e a objetificação a elas impostos pela cultura universal para tornarem-se sujeito político identitário com capacidade de participação paritária na construção de um novo parâmetro normativo de justiça social que garanta o respeito pelas diferenças e a igualdade de oportunidades na busca pela igual estima social. 


\section{REFERÊNCIAS}

BAIRROS, Luiza. A Mulher Negra e o Feminismo. In: O Feminismo do Brasil: reflexões teóricas e perspectivas. Ana Alice Alcantara Costa, Cecília Maria B. Sardenberg, organizadoras. Salvador: UFBA / Núcleo de Estudos Interdisciplinares sobre a Mulher, 2008.

BAIRROS, Luiza. Nossos feminismos revisitados. Revista Estudos Feministas/Dossiê Mulheres negras. Rio de Janeiro:IFC/UFRJ,3(2):458. 1995.

BARALDI, Camila Bibiana Freitas; PERUZZO, Pedro Pulzatto. DEMOCRACIA E DIREITOS HUMANOS: A PARTICIPAÇÃO SOCIAL DAS MINORIAS. Revista Eletrônica do Curso de Direito da UFSM, Santa Maria, RS, v. 10, n. 1, p. 347-370, out. 2015.

BARBOSA, W.N. \& SANTOS, J.R. Atrás do muro da noite: dinâmicas das culturas afro-brasileiras. Brasília: Minc/Fundação Cultural Palmares, 1994.

CARNEIRO, Sueli. Enegrecer o feminismo: A Situação da Mulher Negra na América Latina a partir de uma perspectiva de gênero. In: Ashoka Empreendimentos Sociais \& Takano Cidadania (Orgs.). Racismos contemporâneos. Rio de Janeiro: Takano Editora, 2011.

COLLINS, Patricia Hill. Aprendendo com a outsider within: a significação sociológica do pensamento feminista negro. Revista Sociedade e Estado. [online]. 2016, vol.31, n.1 [cited 2019-02-18].

COLLINS, Patricia Hill. Comment on Hekman's "Truth and Method: Feminist Standpoint Theory Revisited": Where's the Power? Signs, v. 22, n. 2, p.375-381, 1997.

DAVIS, Angela. A democracia da abolição: para além do império das prisões e da tortura. Tradução Artur Neves Teixeira. Rio de Janeiro: DIFEL, 2009.

FERNANDES, Florestan. 0 negro no mundo dos brancos. Apresentação de Lilia Moritz Schwarcz. 2. ed. rev. São Paulo: Global, 2007.

FLORES, Joaquín Herrera. Direitos Humanos, interculturalidade e racionalidade de resistência. Seqüência, Florianópolis, UFSC, v. 23, n. 44, 2002.

FRASER, Nancy. Reconhecimento sem ética ? Lua Nova, São Paulo, n. 70, p. 101-138, 2007.

FRASER, Nancy. Redistribuição, Reconhecimento e Participação: Por uma Concepção Integrada da Justiça. In: SARMENTO, Daniel; IKAWA, Daniela; PIOVESAN, Flávia (Coords.). Igualdade, Diferença e Direitos Humanos. Rio de Janeiro: Lumen Juris, 2008.

FREYRE, Gilberto. Casa-grande \& senzala. 40. ed. Rio de Janeiro: Record, 2000.

FRISCHEISEN, Luiza Cristina Fonseca. A construção da igualdade e o sistema de justiça no Brasil: alguns caminhos e possibilidades. Rio de Janeiro: Lumen Juris, 2007. 
GOMES, Nilma Lino. O Movimento Negro Educador: saberes construídos nas lutas por emancipação. Rio de Janeiro: Vozes, 2017.

GONZÁLES, Lélia. Racismo e sexismo na cultura brasileira. Revista Ciências Sociais Hoje, Anpocs, n. 2, Rio de Janeiro, 1984.

HALL, Stuart. Da Diáspora: Identidades e mediações culturais. Tradução de Adelaine la Guardia Resende et al. Belo Horizonte: UFMG Editora, 2003.

hooks, bell. Mulheres negras: moldando a teoria feminista. Revista Brasileira de Ciência Política, n. 16, p. 193-210. abr. 2015.

LAFER, Celso. A reconstrução dos direitos humanos: a contribuição de Hannah Arendt. Estudos Avançados, São Paulo, v. 11, n. 30, 1997.

MATTOS, Patrícia de Castro. A sociologia política do reconhecimento: as contribuições de Charles Taylor, Axel Honneth e Nancy Fraser. São Paulo: Annablume, 2006.

MOREIRA, Núbia Regina. 0 feminismo negro brasileiro: um estudo dos movimentos de mulheres negras no Rio de Janeiro e São Paulo. (Dissertação) Mestrado em Sociologia pela Universidade Estadual de Campinas/SP, 2007.

MOREIRA, Núbia Regina. Movimento feminista negro no Brasil. 2018. Disponível em: <https: / /www.youtube.com/watch?v=TQa0La1YlFw> Acesso em: 08/11/2018.

MULLER, Crisna Maria; MOREIRA, Dirceia. A EFETIVAÇÃO DOS DIREITOS HUMANOS NA CONCEPÇÃO MULTICULTURAL: CONSTRUÇÃO DA CIDADANIA COSMOPOLITA. Revista Eletrônica do Curso de Direito da UFSM, Santa Maria, RS, v. 11, n. 1, p. 71-89, jun. 2016.

MUNANGA, Kabengele. As ambigüidades do racismo à brasileira. In: KON, Noemi Moritz; ABUD, Cristiane Curi; SILVA, Maria Lúcia da. (orgs.) 0 racismo e o negro no Brasil: questões para a psicanálise. São Paulo: Perspectiva, 2017.

PEDRO, Joana Maria. Traduzindo o debate: o uso da categoria de gênero na pesquisa histórica. História , Franca, v. 24, n. 1, p. 77-98, 2005.

PINTO, Céli Regina Jardim. Uma história do feminismo no Brasil. São Paulo: Fundação Perseu Abramo, 2003.

RIBEIRO, Djamila. O que é lugar de fala? Belo Horizonte (MG): Letramento, 2017.

RIZZINI, Irma. Assistência à infância no Brasil: uma análise de sua construção. Rio de Janeiro: Ed. Universitária Santa Úrsula, 1993.

SARMENTO, Daniel. Direito Constitucional e Igualdade Étnico-Racial. In: SOUZA, Douglas Martins; PIOVESAN, Flávia (Coords.). Ordem Jurídica e Igualdade Étnico-Racial. Rio de Janeiro: Lumen Juris, 2008.

SANTOS, Boaventura de Sousa. A gramática do tempo: para uma nova cultura política. São Paulo: Cortez, 2006. (Col. Para um novo senso comum, v. 4). 
SANTOS, Boaventura de Sousa. Introdução para ampliar o cânone do reconhecimento, da diferença e da igualdade. In: (Org.). Reconhecer para libertar: os caminhos do cosmopolitismo multicultural. Rio de Janeiro: Civilização Brasileira, 2003a.

SANTOS, Boaventura de Sousa. Por uma concepção multicultural de direitos humanos. In: (Org.). Reconhecer para libertar: os caminhos do cosmopolitismo multicultural. Rio de Janeiro: Civilização Brasileira, 2003b. (Coleção Reinventar a Emancipação Social: para novos manifestos. v. 3).

SCHWARCZ, Lilia Moritz. 0 espetáculo das raças: cientistas, instituições e questão racial no Brasil - 1870-1930. São Paulo: Companhia das Letras, 1993.

SILVA, Marcelo L. da. A história no discurso do Movimento Negro Unificado: os usos políticos da história como estratégia de combate ao racismo. Campinas, SP, 2007. Dissertação. (Programa de pós-graduação em História) - UNICAMP, Campinas, 2007.

WALSH, Catherine. Interculturalidade crítica e pedagogia decolonial: in-surgir, re-existir e reviver. In. CANDAU, Vera Maria (Org.). Educação intercultural na América Latina: entre concepções, tensões e propostas. Rio de Janeiro: 7 Letras, 2009.

WERNECK, Jurema. Nossos passos vêm de longe! Movimentos de mulheres negras e estratégias políticas contra o sexismo e o racismo. Revista da Associação Brasileira de Pesquisadores/as Negros/as (ABPN), [S.l.], v. 1, n. 1, p. 07-17, jun. 2010.

WOLKMER, Antônio Carlos. Para uma sociologia jurídica no Brasil: desde uma perspectiva crítica e descolonial. Revista Brasileira de Sociologia do Direito, v. 4, n. 3, set./dez. 2017.

\title{
COMO FAZER REFERÊNCIA AO ARTIGO (ABNT):
}

\begin{abstract}
LIMA, Fernanda da Silva Lima; CAPORAL, Angélica Azerego Garcia. Feminismo negro no Brasil e luta por reconhecimento: um diálogo com a teoria da justiça de Nancy Fraser. Revista Eletrônica do Curso de Direito da UFSM, Santa Maria, RS, v. 15, n. 1, e37166, jan./abr. 2020. ISSN 1981-3694. DOI: http://dx.doi.org/10.5902/1981369437166. Disponível em:
\end{abstract}

https://periodicos.ufsm.br/revistadireito/article/view/37166 Acesso em: dia mês. ano.

Direitos autorais 2020 Revista Eletrônica do Curso de Direito da UFSM

Editores responsáveis: Rafael Santos de Oliveira e Angela Araujo da Silveira Espindola

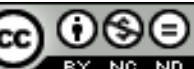

Esta obra está licenciada com uma Licença Creative Commons Atribuição-NãoComercial-SemDerivações 4.0 Internacional. 


\section{SOBRE AS AUTORAS}

FERNANDA DA SILVA LIMA

Doutora e Mestre em Direito pela Universidade Federal de Santa Catarina. Bacharel em direito pela Universidade do Extremo Sul Catarinense. Professora Permanente no Programa de Pós-Graduação em Direito da Unesc (Mestrado em Direito). Professora titular da disciplina de Direitos Humanos na UNESC. Vice líder do Núcleo de Estudos em Direitos Humanos e Cidadania (NUPEC/UNESC). Líder do Grupo de Pesquisa em Direitos Humanos, Relações Raciais e Feminismo[s]. Integrante do NEAB/UNESC (Núcleo Núcleo de Estudos Étnico-Raciais, Afrobrasileiros, Indígenas e Minorias). Pesquisadora na área de Direito Público com linha de pesquisa Direitos Humanos, Cidadania e novos direitos com interesse nos seguintes temas: relações raciais, feminismo negro, reconhecimento e decolonialidade.

\section{ANGÉLICA AZEREgo GARCIA CAPORAL}

Mestranda em Direito pela Universidade do Extremo Sul Catarinense - UNESC (2018). Possui graduação em Direito pela Universidade do Sul de Santa Catarina (2003). Pós-Graduação "Lato Sensu" pela Faculdade de Ciências Sociais de Florianópolis-CESUSC em Direito Civil e Processual Civil (2004), e Pós-Graduação "Lato Sensu" pela Universidade AnhangueraUniderp em Direito Notarial e Registral (2013). Atualmente é Escrivã de Paz: Tabeliã de Notas e Oficial de Registro Civil na Escrivania de Paz do Município de Morro Grande, Comarca de Meleiro/SC. Participante do Grupo de Pesquisa em Direitos Humanos, Relações Raciais e Feminismo[s], do(a) Universidade do Extremo Sul Catarinense - UNESC. Integrante do Grupo de Pesquisa em Direitos Humanos e Cidadania - NUPEC/UNESC. Mediadora certificada pelo Tribunal de Justiça de Santa Catarina (2017). Tem experiência na área de Direito, com ênfase em Direito Civil, Direito Notarial e Registral, Mediação e Conciliação. 